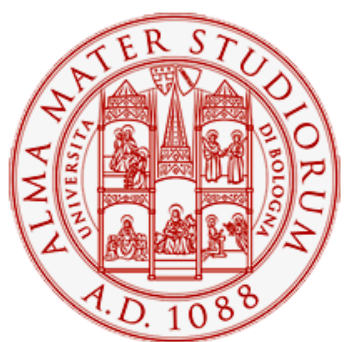

Alma Mater Studiorum - Università di Bologna DEPARTMENT OF ECONOMICS

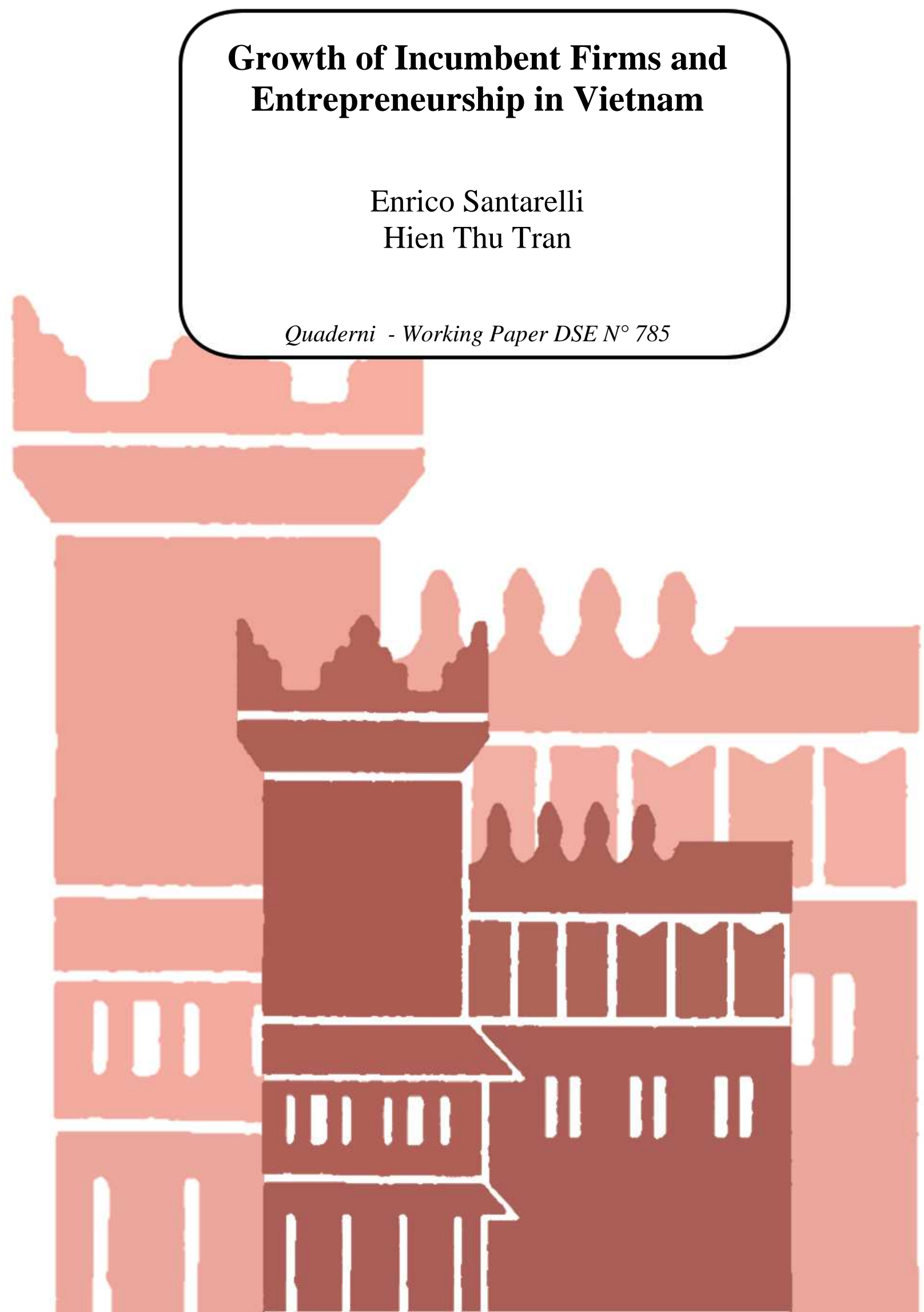




\title{
Growth of Incumbent Firms and Entrepreneurship in Vietnam
}

\author{
by \\ Enrico Santarelli \\ University of Bologna, Department of Economics; Piazza Scaravilli, 2 - 40126 Bologna, Italy; \\ tel. +39051 2098487; e-mail: enrico.santarelli@unibo.it \\ Hien Thu Tran \\ CIFREM - Doctoral School of Economics and Management - University of Trento; Via Inama, 5 - \\ 38100 Trento, Italy; e-mail thuhien232@yahoo.com
}

\begin{abstract}
This paper analyzes the relationship between the performance of incumbent firms and the net entry of new firms by combining different theoretical views of entrepreneurship. It shows that new knowledge and ideas created but not commercialized by incumbents are an important source of entrepreneurial opportunities for nascent firms. Different regression models to treat dynamics and endogeneity issues are applied to test the research hypothesis that growth of incumbent firms in a region will stimulate start-up activities by creating new profit opportunities for potential entrepreneurs. Vietnam's regional micro-data from 2000 to 2008 are used for this test. Four controlling indicators - entrepreneurial demand, market structure, regional economic environment, and market innovativeness - are found to exert a statistically significant effect on new entries.
\end{abstract}

Keywords: Firm growth; Entrepreneurship; Region; Vietnam.

JEL Classification: L25 ; L26 ; O53 ; R12 


\section{Introduction}

This paper explores the relationship between performance of incumbent firms and entrepreneurship in Vietnam. In the field of entrepreneurship, the relationship between performance of incumbent firms and entrepreneurship is theoretically explained by two hypotheses: knowledge-spillover hypothesis (Schumpeter) and error-correction hypothesis (Kirzner). According to the knowledge spillover hypothesis, incumbent firms invest into R\&D to generate innovations. However, the knowledge and ideas generated from incumbent firms' R\&D investment are not fully encapsulated and captured by the incumbent firms due to the limitation of their productive capabilities. In other words, a certain amount of knowledge may leak outside and possibly captured by outsiders. This "knowledge filter" (Acs et al., 2009) may result in profit opportunities for new entrepreneurs. The error-correction hypothesis on the other hand argues that incumbent firms, on the process of exploiting their profit opportunities, will commit errors at various degrees due to their knowledge limitations. Some errors may be recognized and corrected by incumbent firms themselves. However, many other errors are unknown by incumbent firms and become the source of opportunities for nascent entrepreneurs to discover. Once new entrepreneurs pursue these opportunities they contribute to the correction of errors generated by incumbent firms in the previous round. Since incumbent firms are not capable of preventing new entrepreneurs from recognizing and acting to correct these errors, new entrepreneurs always gain benefits from past performances of incumbent firms.

Some recent empirical studies test this relationship based on the innovation hypothesis. Most of empirical studies have been conducted in developed countries where $R \& D$ activities prevail and data on R\&D activities are easily accessed. However, the case of a developing country is different. Firms in developing countries often do not have a separate budget and plan for $R \& D$ activities to support their production activities. As a consequence, the knowledge spillover effect of R\&D activities is hard to be controlled, isolated and explored. It is therefore expected that the relationship between the performance of incumbent firms and entrepreneurship is determined largely by error-correction effect which is intermingled with $R \& D$ effect as well. Developing countries could be considered as a laboratory for testing the joint heuristics of both innovation and error-correction effect.

In empirical studies, the innovation effect upon our concerning relationship could be conducted at the micro level since we can identify $R \& D$ investments in a certain number of incumbent firms and then trace their effects on other firms, including new firms, in different proxy distance. But we cannot do that to examine the error-correction effect since we do not know the origin of errors occurring in market. However, we can assume that the aggregate performance of incumbent firms within a region will generate errors so that a certain number of nascent entrepreneurs in that region have chance to capture. Certainly, innovation effect also contributes into this relationship. In other words, while we cannot trace back the effect of the relationship between the performance of a particular incumbent firm and particular new firms we can observe this relationship at the aggregate or regional level; and both innovation and errorcorrection effects would be tested together.

The contribution of the paper is twofold. From a theoretical viewpoint, an analytical integrated framework on the dynamic relationships among incumbent firms, 
entrepreneurship, and firm entry is set up. From an empirical viewpoint, use of firmlevel data from the General Statistics Office (GSO) of Vietnam dealing with 61 provinces over the 2000-2008 period allows a thorough analysis of such a relationship. The paper is structured as follows: Section 2 discusses how the issues of firm growth and of firm entry and survival have been analyzed respectively within the opportunitybased and the knowledge filter approaches. Section 3 introduces theoretical framework and main research hypotheses. Section 4 contains econometric strategy and empirical results based on regional micro-data on annual basis from 2000 to 2008 in Vietnam. The paper ends with some concluding remarks in Section 5.

\section{Incumbent Firms, Entrepreneurial Opportunities, and Entry}

Edith Penrose (1959, p. xii) depicts the firm as a collection of physical and human resources whose services are made productive by a 'coherent administrative organization'. As long as resources are used productively, the firm will continue to grow and, therefore, accumulate resources. Additional accumulation of productive resources widens the firm's productive opportunities, by increasing the possibilities of deploying resources in higher productive ways. However, although a firm's productive possibilities always expand with number and variety of available resources, the pool of its productive opportunities does not necessarily expand equivalently: context and uniqueness of the firm's administrative organization limits its possibility to seize all productive opportunities.

Penrose's concept of "productive opportunity" shares some aspects with that of "entrepreneurial opportunity", described by Scott Shane (2003, p. 18) as "a situation in which a person can create a new means-ends framework for recombining resources that the entrepreneur believes will yield a profit". Here a new means-ends framework is a new way of thinking on the relationship between actions and outcomes. Shane's (2003) "entrepreneurial opportunities" are a subset of Penrose's "productive opportunities". As the firm continues to grow, it generates a larger number of productive resources that expand the available resource pool and, therefore, the firm's potential to recombine resources at higher values. However, due to the limited flexibility of resources, especially human capital, only a fraction of these possibilities are exploited by the firm. This way of interpreting Penrose's idea has an important implication, namely that the firm has to keep its entrepreneurial opportunities in balance with its productive possibilities. This implication is also considered by the knowledge-based theory of the firm, which views the firm as a set of productive and dynamic capabilities to do well certain things (Dosi and Marengo, 2000). ${ }^{1}$ The firm is represented as a processor of knowledge or locus for the creation, selection, use, and development of knowledge (Fransman, 1999; Cohendet et al., 2000). To 'do well certain things', a firm has to turn different sets of individual knowledge and capabilities into 'coherent sets' or competences (Teece et al., 1997). Any partial minor change in a given set of a firm's routines may require systemic changes and adjustments in other aspects of the firm's activities, which might be hard to accomplish due to the tacit nature of many organizational routines (Nelson and Winter, 1982). At any given point in time, according to the notion of path dependence, firms must follow a certain trajectory or path of competence development. Not only this path defines what choices are open to

\footnotetext{
${ }^{1}$ Following Teece et al. (1997, p. 509), dynamic capabilities correspond to "the firm's ability to integrate, build, and reconfigure internal and external competences to address rapidly changing environments". In the context of the present paper they define the internal and external knowledge upon which a firm builds to respond to changes in the competitive environment.
} 
the firm today, but it also puts bounds around what its repertoire is likely to be in the future (Teece et al., 1997). Therefore, a firm's dynamic capability constrains the richness of the menu of new opportunities from which it may select, and subsequently its performance in a changing environment.

According to the "knowledge filter theory of entrepreneurship" (Audretsch, 1995; Audretsch et al., 2005; Acs et al., 2009), the most important advantage of nascent entrepreneurs is that they do not need to invest into new knowledge as incumbent firms have to (Audretsch et al., 2005). Nascent entrepreneurs can enjoy the free lunch because of the appearance of the knowledge filter within incumbent firms and knowledgecreating institutions. Here, the knowledge filter is the gap between new knowledge created by a given organization and new knowledge commercially exploited by such organization. Due to the basic conditions inherent in new knowledge, like high uncertainty, asymmetries, and transaction costs, the management team of incumbent firms has to leave away many new ideas which other individuals or agents evaluate as worth to pursue (ibid.: 75-6). As Acs et al. (2009) state, the divergence in valuation of knowledge across economic agents and within the decision-making process of incumbent firms can induce agents to start new firms as a mechanism to appropriate the (expected) value of their knowledge. Further, nascent entrepreneurs can freely exploit the technological and managerial experience and knowledge accumulated while working as paid employees and take advantage of their current customer and supplier linkages without initial investments as well (Shane, 2003). They have to decide when and how to enter the market, taking into account the current environmental conditions (Lévesque and Shepherd, 2004).

The knowledge filter theory of entrepreneurship gives also another indication of what determines the entry rate of new firms at the aggregate level: spatial proximity. Since knowledge spillovers are geographically bounded and localized within close geographical proximity to the knowledge source (Audretsch et al., 2005), new firms tend to locate close to knowledge sources, such as large incumbent firms or universities/research institutions. Thus, not all new start-up firms enjoy benefits of investments into new knowledge from incumbent institutions at the same level. Rather, only start-up firms in the region characterized by strong growth of incumbent firms and technical intensiveness (abundant research and development personnel and technical personnel) can benefit from such investment. In this sense, the entry rate of new firms in a region is determined by investment of incumbent institutions into new knowledge.

A theoretical explanation specifically designed for some of the Asian and LatinAmerican most successful economies during the last decades, and consistent with the knowledge spillover theory, should be also taken into account. This can be defined as the "imitation" hypothesis (Hausmann and Rodrik, 2003), submitting that those entrepreneurs who make the "right investment decision", even in labor-intensive or natural-resource based productions can orient the investment of other entrepreneurs. This imitation effect is due to the fact that the initial entrepreneur making the "discovery" is able to appropriate only a fraction of the social value that this discovery generates, while signaling to other potential entrepreneurs the existence of opportunities. As a consequence, "learning what can be produced" is a type of entrepreneurship that may foster growth in transition/developing countries.

Many empirical studies have tested the importance of the knowledge spillovers generated through $\mathrm{R} \& \mathrm{D}$ activities of existing firms, universities, and research institutions. The empirical evidence supports the knowledge filter theory of entrepreneurship. In particular, Audretsch (1995) and Caves (1998) find out that industries with a greater investment in new knowledge exhibit higher startup rates and 
viceversa, whereas Audretsch and Feldman (1996) and Audretsch and Lehmann (2005) provide evidence concerning the spatial dimension of knowledge spillovers. In general, the greater the local knowledge stock in a region, the richer the pool of entrepreneurial opportunities and the higher the level of absorptive capacity for knowledge of that region. Subsequently, the region is expected to stimulate more new entries and experience higher growth rates (Mueller, 2007).

\section{An Integrated Analytical Framework}

None of the empirical studies summarized in the previous section have identified the actual mechanisms which transmit knowledge; rather, the spillovers have been implicitly assumed to automatically occur within a geographically bounded spatial area (Audretsch et al., 2005). In this section we investigate the mechanism underlying entrepreneurship as the realization of entrepreneurial opportunities. Based on the above discussions, we build an integrated framework to indicate the dynamic interactions among entrepreneurship, firm growth, and new firm formation (Figure 1).

\subsection{Description of the Diagram}

The diagram presented in Figure 1 includes stocks and flows:

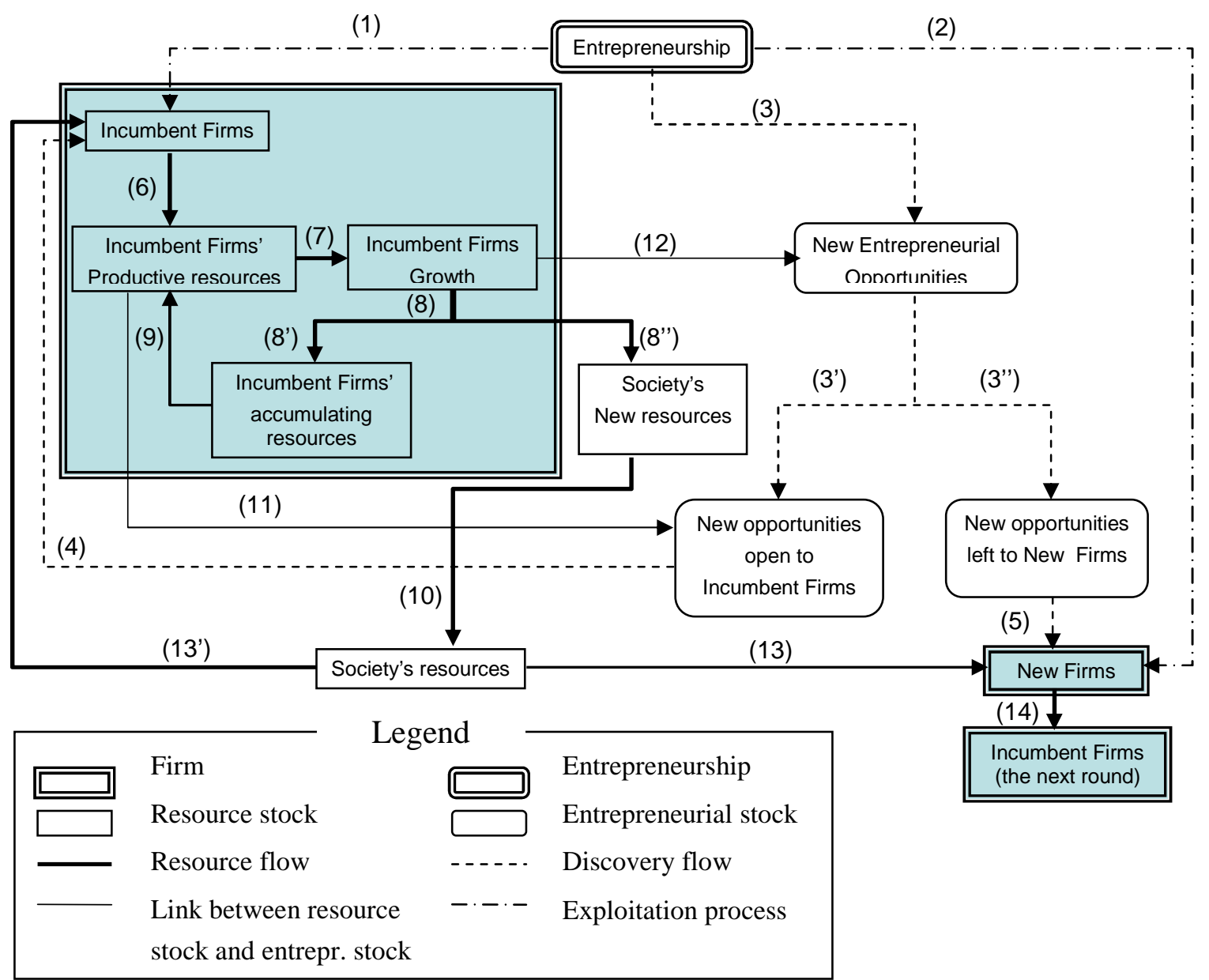

Fig. 1. The Relationships Between Entrepreneurship, New Firm Formation, and Firm Growth. 


\section{A. Stocks}

- Firm: collection of productive (human and physical) resources guided by an entrepreneurial team (Penrose, 1959). There are two types of firm:

+ Incumbent firm: remained active for a certain number of years ( $>3)$.

+ New (entrepreneurial) firm: just established, not more than three years old.

- Entrepreneurship: activity involving the discovery and exploitation of entrepreneurial opportunities (Shane, 2003).

- Entrepreneurial opportunity: situation involving creation of a new means-ends framework for recombining resources that will likely yield a profit (Shane, 2003).

- Productive resource: means providing services to entrepreneurs. New productive resources are partly retained by incumbents and partly distributed to the society.

\section{B. Flows}

There are three types of flow in the diagram: entrepreneurial flow, resource flow, and the link between the resource domain and the entrepreneurial domain.

- Entrepreneurial flows: dichotomized into two types according to two entrepreneurial acts: entrepreneurial discovery and entrepreneurial exploitation.

+ Entrepreneurial discovery: individuals' effort to recognize entrepreneurial opportunities generated by incumbents (relationship 3). These include: opportunities which match with the constraints resulting from incumbent firms' productive resources, and hence, belong to incumbent firms' stock of productive opportunities (relationship 4); opportunities which are not evaluated worthy or feasible to be exploited by incumbent firms but prove beneficial to other individuals, and hence belong to new firms' stock of productive opportunities (relationship 5).

+ Entrepreneurial exploitation: occurring when entrepreneurs decide to gather resources and combine them into organizing entities to exploit the recognized entrepreneurial opportunies. If entrepreneurial opportunities are recognized by those belonging to the incumbent firms, they will be exploited by the incumbent firms (relationship 1), whereas if they are recognized by those who desire to run the new firms, they will be exploited by the new firms (relationship 2).

\section{- Resource flows:}

+ Incumbent firms: Already possessing a certain stock of productive resources, they can mobilize additional resources from the society to pursue new opportunities (relationship 6) and grow (relationship 7). The output growth of incumbents is measured as an increase in productive resources (relationship 8) that is either retained (relationship 9) or pumped into the society's reservoir (relationship 10).

+ New (entrepreneurial) firms: Created by mobilizing productive resources from the society's reservoir (relationship 13). After some years of operation (e.g. three years), new surviving firms join the club of incumbent firms (relationship 14).

\section{- Links between entrepreneurial domain and resource domain:}

+ Growth of incumbent firms and new entrepreneurial opportunities: Firms grow by expanding the stock of productive resources. New productive resources and technologies are in turn sources of new entrepreneurial opportunities for all market players (relationship 12).

+ Incumbent firms' productive resources and incumbent firms' productive opportunities: the existing productive resources of incumbents constrain and limit the entrepreneurial team of these firms to exploit the full range of entrepreneurial opportunities which they create for the society (relationship 11). 


\subsection{Hypotheses}

When entrepreneurs of incumbent firms discover opportunities and want to realize them (relationship 1, 3->3', and 4), they use accumulated resources in the form of R\&D investment (relationship 6 and 7) to create new means-ends frameworks. The obvious outcome of this process is the growth of incumbent firms. But a higher investment in new knowledge by incumbents generates a larger knowledge spillover or a greater number of entrepreneurial opportunities for nascent entrepreneurs, therefore fostering new firm formation (relationship 12 and 3"). Further, the growth of incumbents increases the stock of productive resources available for the society, in this way relaxing the capital constraints faced by nascent entrepreneurs (relationships 10 and 13).

Hypothesis 1: The growth of incumbent firms located in the region generates localized externalities and spillovers.

Accelerated growth by incumbent firms implies that the number of firms having less excess profit tends to lower. This implies that the number of firms which have to leave the industry tends to decrease. ${ }^{2}$ In combination, net entry tends to have a strong positive correlation with the growth of incumbent firms in the same period.

Hypothesis 2: The rate of new firm formation in a region has a strong positive correlation with the growth of sales of incumbent firms in that region.

\section{Empirical Evidence}

The majority of studies dealing with the regional determinants of new firm formation have focused on advanced countries (for a survey cf. Verheul et al., 2009; Santarelli et al., 2009). Among studies dealing with developing countries, those by Gaygisiz and Koksal (2003) for Turkey and by Wang (2006) for Taiwan are among the most noteworthy. The paucity of suitable regional-level data is one of the main impediments to research in these countries. Accordingly, this section explores the determinants of new firm formation in Vietnam by using a unique set of annual regional micro-data from 2000 to 2008. We employ different methodological treatments to account for unobserved location- and period-specific influences, the endogeneity issues of incumbent firms' growth as well as the dynamics of any potential regional performance shocks which are capable of biasing the results.

\subsection{Data Description}

We use panel regional-level data for 61 provinces in Vietnam from 2000 to 2008. All firms reaching a certain size threshold or desiring to adopt a formal ownership form (partnership, limited liability, corporation, etc.) are required to register into the National Enterprise Database that is managed and aggregated annually at provincial level by the General Statistics Office. The database has some limitations. First, it does not contain data for the entrepreneurial activities of small households, who are not required to officially register. Second, it does not allow singling out firm registrations and cancellations: thus, we can only calculate the net number of new entries as difference between total number of firms included in a given year and the same value in previous

\footnotetext{
${ }^{2}$ Within a Marshallian partial equilibrium framework, all firms have U-shaped long-run average cost curves with identical values at their minimum points. Positive or negative excess profits cause new firms to enter or existing firms to leave the industry. The expansion or contraction of industry output through changes in the number of firms continues until a long-run equilibrium is established with zero excess profits, i.e. when output prices equal the minimum average cost.
} 
year. Finally, from 2004, for certain regions, new provinces were created through separations from the existing ones. This has increased the number of Vietnamese provinces to 64 . For simplification, the values related to provinces that were founded after 2004 are added to the provinces from which they were separated.

During the period 2000-2008, net entry determined an increase in the total number of firms by about 16,000 per year, mostly in the private sector. Over the period 20002003, net entry increased slightly, from 9,392 in 2000 to 11,228 in 2003, and to 19,747 in 2004. The period 2005-2008 marked a sharp rise of new firms from 21,632 net entries in 2005 to 49,918 ones in 2008. In general, the increase in the number of firms in the period 2005-2008 was more than double the one of the period 2000-2004. Figure 2 illustrates the increasing presence of private firms and the sharp decline of state-owned ones over the period from 2000 to 2008 , whereas foreign firms maintain a share of about $3 \%$.

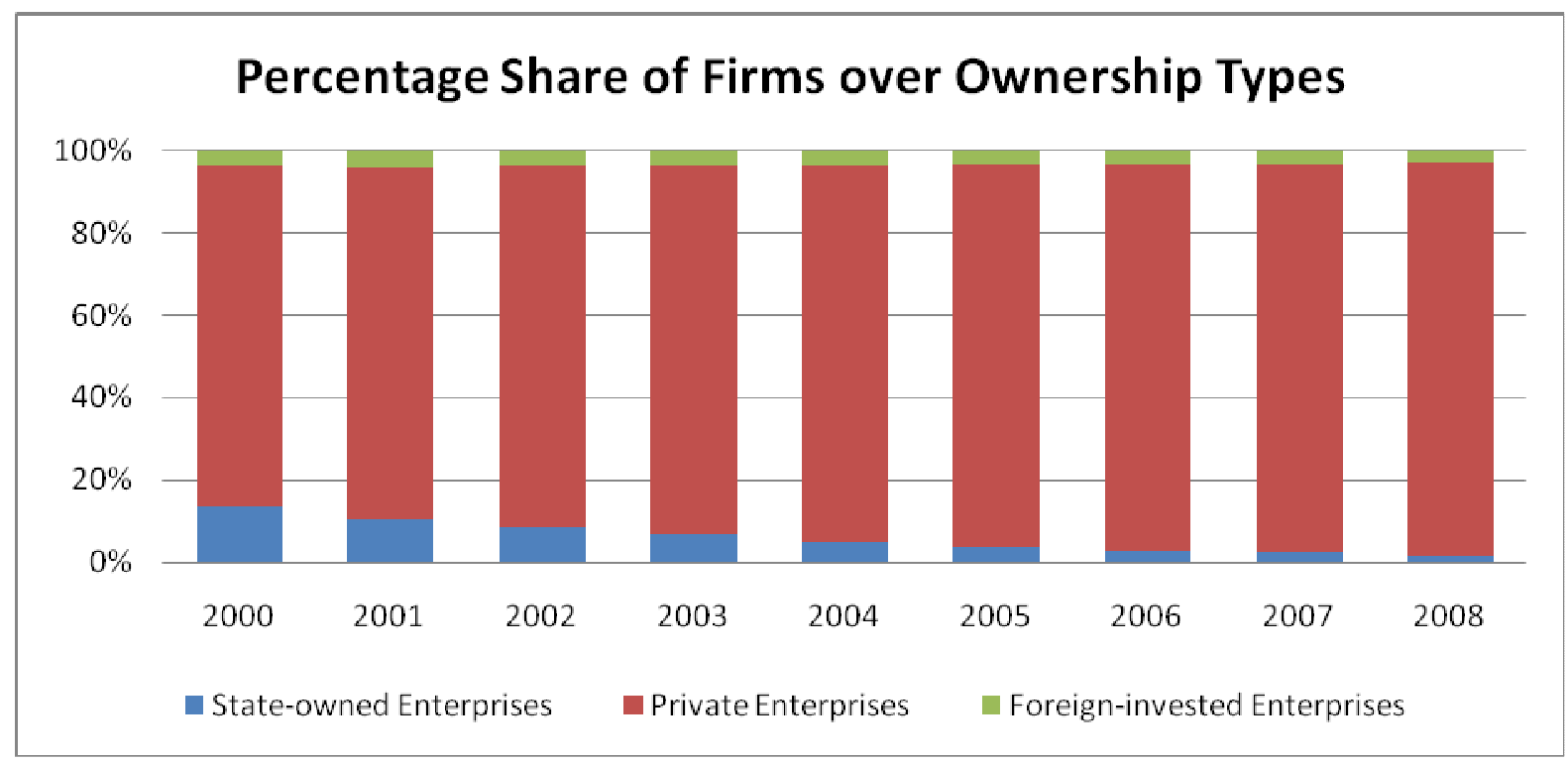

Source: compiled by the authors from GSO (2007)

Fig. 2. Percentage Share of Firms by Ownership Type (2000-2007).

Figure 3 presents the percentage share of enterprises by economic sector in 2000, and figure 4 shows the same percentage in 2006. Comparison of the two figures gives an insightful view of which economic sectors are characterized by higher net entry and how the structure of economic activities shifts overtime from 2000 to 2008. The majority of additions occurred in the construction and real estate trading sectors. Over 8 years, the share of enterprises increases from $3 \%$ to $11 \%$ in construction; from $10 \%$ to $14 \%$ in real estate trading. In general, there has been an increase in the share of enterprises in the infrastructure service sector and a corresponding decrease in agriculture and forestry and manufacturing. 


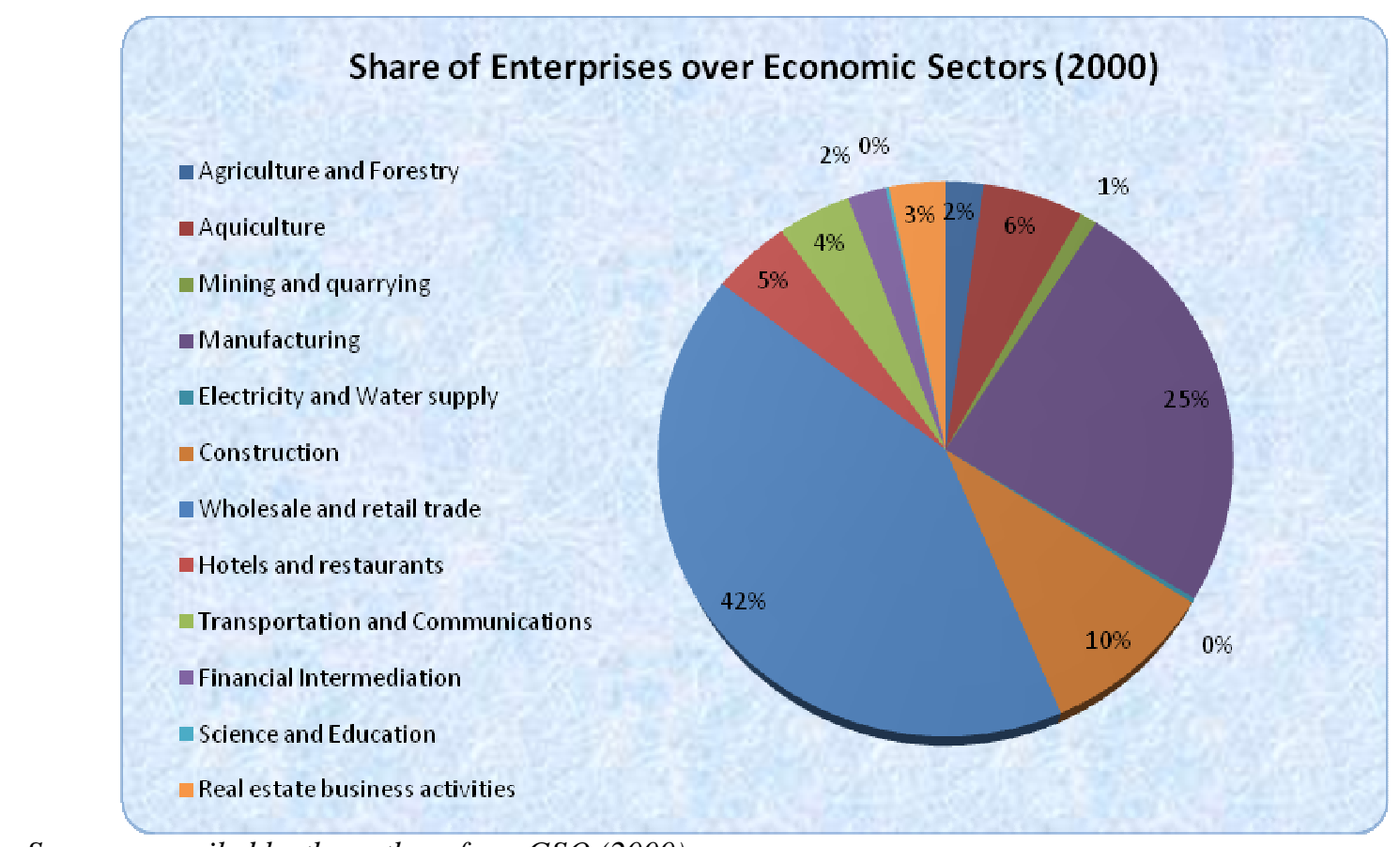

Source: compiled by the authors from GSO (2000)

Fig. 3. Percentage Share of Firms by Economic Sector (2000).

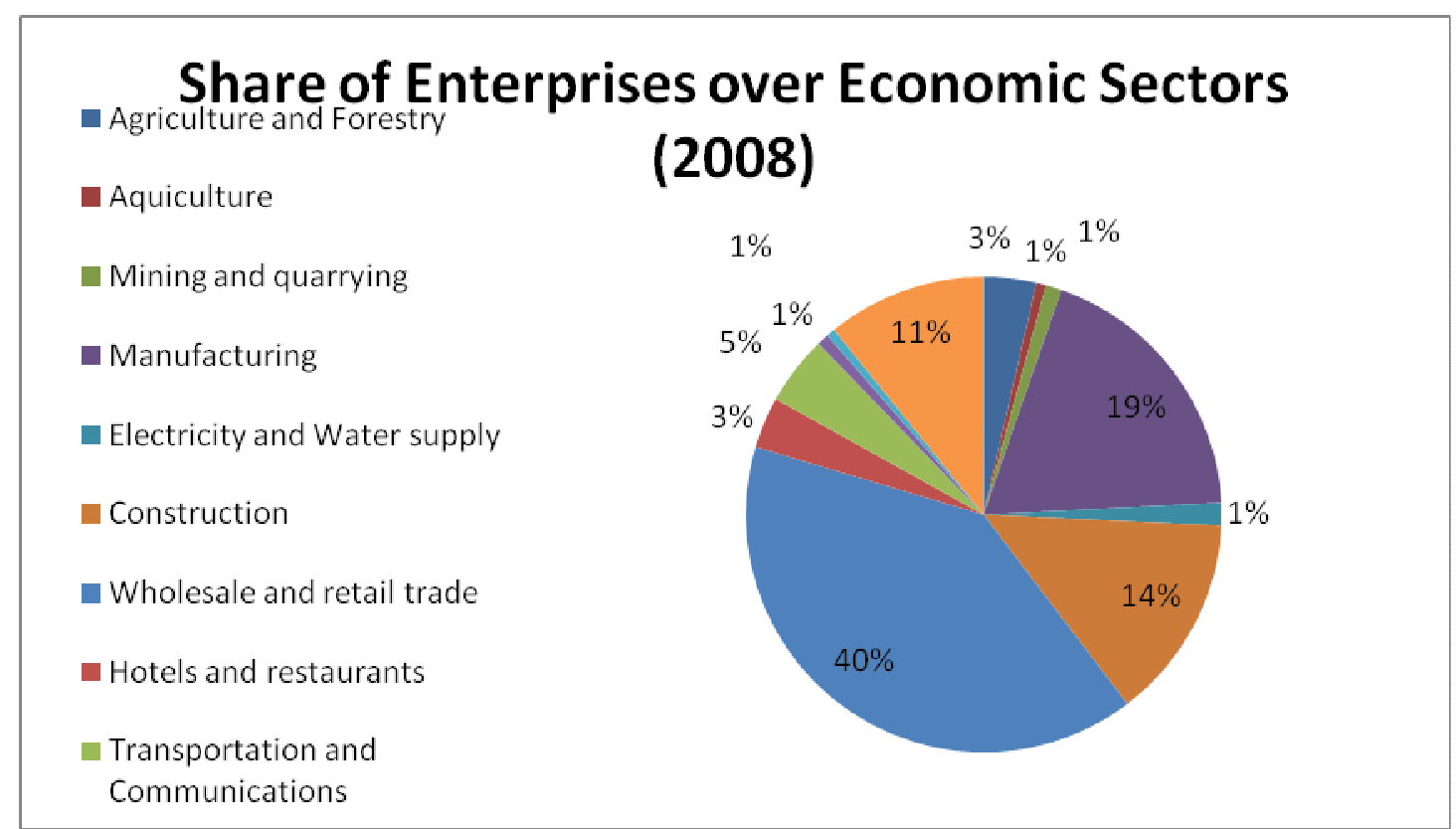

Source: compiled by the authors from GSO (2008)

Fig. 4. Percentage Share of Firms by Economic Sector (2008).

Figure 5 reports the number of enterprises per 1000 persons by province. Provinces in Red River and Mekong delta are the preferable locations. Hanoi, the capital, and Hochiminh city, the biggest commercial and cultural city, have the highest firm density: on average 6 firms/1000 persons, whereas mountainous and rural provinces such as $\mathrm{Ha}$ Giang, Son La, Tuyen Quang are generally not the location choice for entrepreneurs. There is a large divergence between the share of firms per 1000 population in the six densely-populated and highly-developed provinces (Khanh Hoa, Hai Phong, Binh Duong, Da Nang, Hochiminh, and Hanoi) and the remaining provinces. The majority of 
provinces has less than 1 firm per 1000 persons (55/61 provinces) whereas the other 6 provinces have from 2 to 6 firms per 1000 persons.

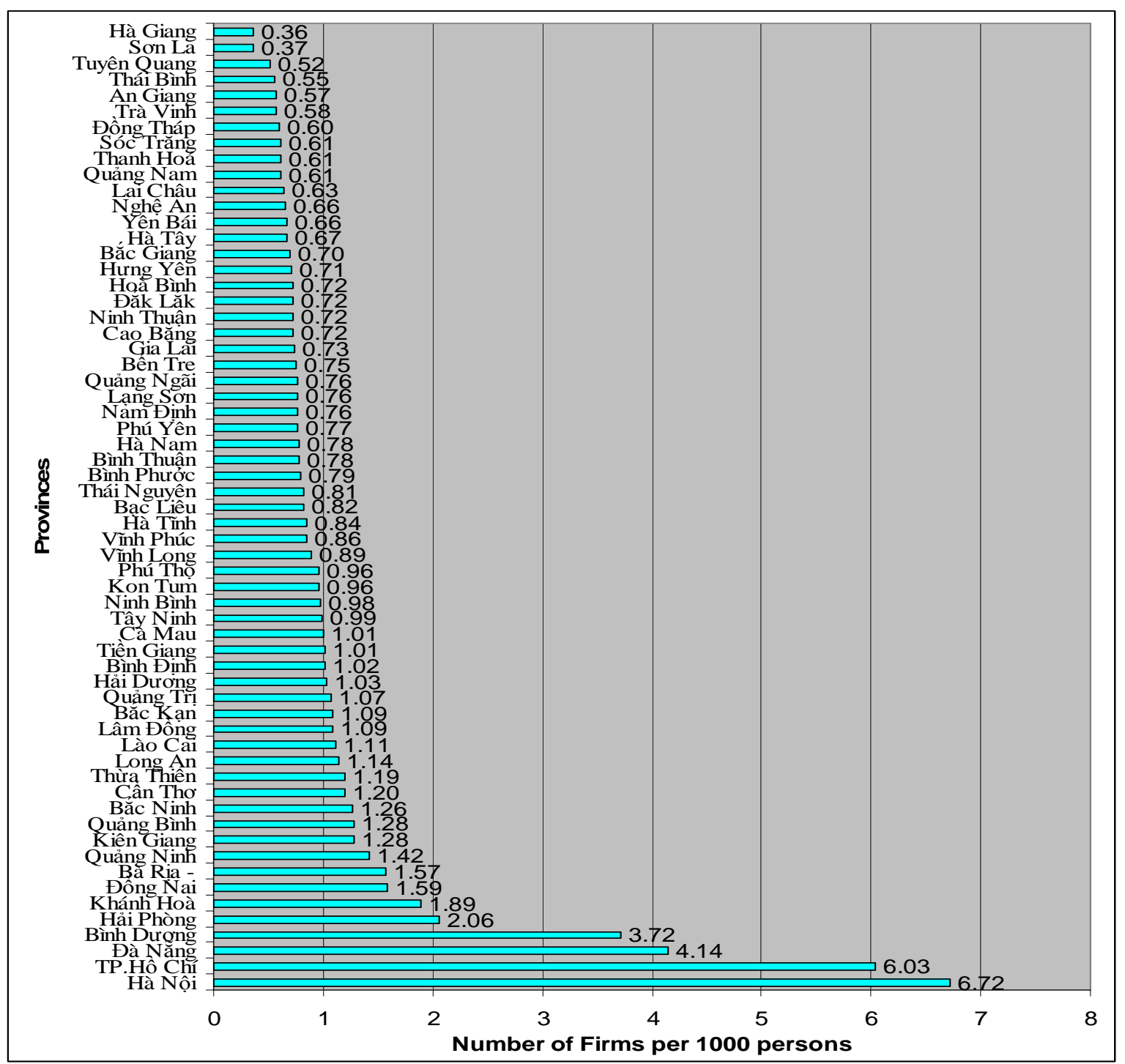

Fig. 5. Number of Firms per 1,000 Persons in each Province.

\subsection{Operationalization of Variables}

Dependent variable Different measures of new firm entry produce strikingly different results. Two approaches are usually adopted to compare start-up rates across regional markets (Santarelli et al. 2009).

The ecological approach standardizes the number of entrants relative to the number of firms in existence to investigate the amount of startup activity relative to the size of the existing population of businesses. A measurement bias could occur due to regional heterogeneity in mean establishment size (MES), i.e. average number of employees per establishment that overstates start-up rates in regions where MES is higher and understates them in relatively low MES regions. ${ }^{3}$

3 Audretsch and Fritsch (1994) insert MES as explanatory variable to control for possible measurement biases. 
The labor market approach standardizes the number of new firms with respect to the size of the workforce. It operationalizes the concept of entrepreneurial choice proposed by Evans and Jovanovic (1989), according to which all firms are the result of individual actions. Each person in the labor pool is considered as a nascent entrepreneur, and has the potentiality to set up his own business (Audretsch and Fritsch, 1994).

Due to data constraints, we use the labor market approach. As only data on the number of firms in existence at the end of each year are available, a net measure of the difference between total number of new entries and total number of exiting firms will be used in our analysis, rather than the gross entry rate. Our measure proxies the success of regions in retaining new firms once they have been created, therefore capturing the potential long term impact of new firms on the local economy (Hart and Gudgin, 1994).

Independent variable: Annual growth of revenues of incumbent firms in a region during the period 2000 to 2006 is adopted to study the relationship between their sales performance and new entries in that region. Empirical evidences in advanced countries often consider incumbents as those firms operating for more than 6 years (Audretsch, 1995). However, one has to consider that in a very dynamic business environment of a transitional economy as Vietnam, the rules of games are continuously changing and the number of new entries is increasing over time. Thus, in this paper, incumbent firms are defined as existing firms aged more than 3 years.

Control variables: control variables can be categorized into two different sets of variables. The first set includes other sources of entrepreneurial opportunities rather than those created by incumbent firms (see Shane, 2003). Each source is represented by one or two specific variables that either have been employed in previous research or reflected the unique regional factors of Vietnam.

- Regional entrepreneurial factors

o Entrepreneurial climate: Small firms are often considered the seedbeds for future entrepreneurs, as their employees display a considerably higher propensity to start their business than those in older firms (Beesley and Hamilton, 1984; Wagner, 2004). From the management perspective, employees in small firms have relatively good possibility of direct contact with business founders who may serve as their role models (Reynolds, 1994). From an economic viewpoint, since employment in small firms is often less secure and well paid than it is in large firms, individuals working for small firms are more prone to entrepreneurship than their more riskaverse peers in large firms (Storey, 1982). ${ }^{4}$ Two proxies will be adopted to reflect entrepreneurial spirit of a particular region: (i) the proportion of micro-sized firms in the total existing firms (1 year lagged) $;^{5}$ (ii) the share of enterprises' labor force in the total regional labor force (1 year lagged). A number of studies have found a positive and statistically significant relation between proportion of small firms and start-up rate (Guesnier, 1994; Keeble and Walker, 1994; Hart and Gudgin, 1994; Piergiovanni and Santarelli, 1995; Fotopoulos and Spence, 1999). However, while Keeble and Walker

\footnotetext{
${ }^{4}$ Fritsch and Falck (2007) suggest that a high promotion of employment in small firms may also indicate a low minimum efficient scale which can be assumed favorable for firm entry.

${ }^{5}$ As most start-ups in Vietnam are very small, the share of micro-sized firms in the total number of enterprises in the region could be a good proxy for its breeding ground for nascent entrepreneurship. In 2006, nearly 60\% of establishments are micro-sized firms (employing less than 10 employees) with approximately 52\% of employment share (GSO, 2006). Here we adopt the World Bank definitions about firm size: Micro enterprises, up to 9 employees; Small enterprises, up to 49 employees; Medium enterprises, up to 299 employees; Large enterprises, more than 300 employees.
} 
(1994) suggest that this effect is only limited to manufacturing sectors whereas the service sector reflects the importance of large firms, Audretsch and Fritsch (1994) could not find the predominance of small firms in manufacturing sectors due to the relevance of economies of scale in manufacturing activities, and Garofoli (1994) founds that this relationship does not hold for Italy, due to its unique structural characteristics.

- Entrepreneurial demand Expanding markets and demand for goods and services are major drivers of firm births. Regional gross domestic income per capita (1-year lagged GDP per capita at competitive price of 1994) is used here as the indicator for the level of demand and welfare. Previous studies such as Audretsch and Fritsch (1994), Reynolds (1994), Davidsson et al. (1994), and Armington and Acs (2002) find out that entry tends to be higher in regions where gross value added per person is higher. However, Kangasharju (2000) and Sutaria and Hicks (2004) do not find any influence of income per capita on new manufacturing firm births, concluding that personal wealth is a relatively minor driver of the decision to start-up a new firm.

Regional structural factors

- Urbanization / Agglomeration Regions with a high population density may have higher start-up rates than rural areas due to better access to large and differentiated markets for production factors such as capital, labor and services. Moreover, agglomeration economies may favor firms' access to the knowledge spillovers of both academic institutions and other firms located in the region. Krugman (1991) offers three reasons for the concentration of firms in agglomerated locations: (i) pooled market for high-skilled labors; (ii) non-pecuniary transactions, or production of non-tradable specialized inputs; and (iii) informational spillovers. However, sunk costs of starting a business (wages, rent for office space, etc.) are usually higher in a highdensity agglomeration than in rural areas. On the other hand, although agglomerations provide a large local output market, a larger number of local suppliers may result in a more intense competitive environment. Two indicators will be adopted to investigate the agglomeration effects on new firm births: population density (1 year lagged) and the share of urban population in the total regional population (1 year lagged). Positive and significant effects of population density on start-up rates can be found in Guesnier (1994), Audretsch and Fritsch (1994), Keeble and Walker (1994), Armington and Acs (2002), and Brixy and Grotz (2007). Whereas the urban incubator theory, i.e. urban areas have advantages as incubators for new firms, is supported for the case of UK (Keeble and Walker, 1994), but not supported for the case of Ireland (Hart and Gudgin, 1994).

- Market structure: the proxy is 1-year lagged mean establishment size (MES), defined as the mean number of employees per establishment. It is measured as the ratio of enterprises' labor force, i.e. total number of employees working in enterprises of all ownership types, over the number of firms in the region. Its coefficient has been hypothesized to be negatively related to regional entry rate since larger average establishment size indicates greater dominance by large firms in the market, as well as greater entry barriers for small start-ups. However, while Armington and Acs (2002) report a negative impact of MES on new firm formation, Audretsch and Fritsch (1994) find no evidence of such effect, and Sutaria and Hicks (2004) even find a positive 
relation between MES and the region's entry rate, due to larger firms outsourcing to smaller neighboring firms specialty goods and services.

- Education background/Innovativeness: A large number of studies emphasize the crucial role of knowledge and ideas as a stimulating source for new business entry (Klepper and Sleeper, 2005; Agarwal et al., 2004; Shane, 2000; Shepherd and DeTienne, 2005). There is no doubt that innovative start-ups are more likely to occur in regions that are characterized by a high level of knowledge and innovative activities. The regional share of technical and $\mathrm{R} \& \mathrm{D}$ personnel in the total labor force is therefore used as a proxy for regional innovation activity. It will measure the regional knowledge stock and innovativeness. The higher the share, the higher the importance of innovation activities for the region.

- Regional economic environment: Economic environment of a region is reflected via the change of GDP, institutions, or investments from the state budget. Change of GDP tells us the change in demand which is an incentive for firms to extend their production activities. However, GDP at provincial level does not have much sense in this aspect since the growth of GDP in a province may create benefits in terms of demand for all relevant firms all over the country rather than merely those within the province. For this reason we do not include GDP growth of province as a control variable reflecting regional economic environment.

Institutional factors are major drivers of entrepreneur's decisions to establish new firms. Unfortunately, we do not have reliable indicators to reflect this factor at the provincial level. Therefore, in this paper, we use only 1-year lagged public investment as an indicator for regional economic environment and presence of public infrastructures. By enhancing a region's attractiveness, public investment may also attract new firms, which further contribute to regional growth. In Vietnam, contingent on annually-proposed macroeconomic strategies, the government will adjust its public investments into each province accordingly. To account for the divergence of economic size of all provinces (large provinces receive more state support than small ones), annual public investment per a person at working age will be used as a proxy for regional economic development.

The second set of variables refers to other motivations to establish new firms rather than those inspired by entrepreneurial opportunities.

Income effect: The growth of average compensation per month of employees working in SMEs is used as proxy for their opportunity cost as nascent entrepreneurs to actually start up their own businesses. We have discussed above the higher potentiality that employees in small firms are prone to become selfemployed. It is plausible that the opportunity cost of their start-up decision is their salaries. The higher the salaries they receive, the less likely they will split off to set up their own establishments.

- Unemployment effect: Regional unemployment may affect the level of start-up activity in contradictory ways (Santarelli et al., 2009). On one hand, unemployed persons face low opportunity costs when setting up their own businesses with no other prospects for employment ("necessity entrepreneurship"). Hence, a high level of unemployment may force individuals to become self-employed workers, especially if residential mobility is unattractive (Reynolds, 1994; Guesnier, 1994; Wang, 2006). On the other hand, high unemployment rates are generally seen as signs of quantitative and structural problems on the labor market (Fritsch, 1992; Storey, 1994; Armington and Acs, 2002). High regional unemployment rates may indicate slow growth, relatively low demand and correspondingly bad prospects 
for a successful start-up, thereby dampening incentives for new firms to locate within the region. Moreover, unemployed persons may have little capital of their own and/or limited access to external finance sources. In fact, empirical evidences reflect these two conflicting forces. While Wagner and Sternberg (2004) suggest that unemployed individuals have a higher propensity to be a nascent entrepreneur than people in employment, Gaygisiz and Koksal (2003) and Sutaria and Hicks (2004) imply a negative significant impact of unemployment rate on new firm entry. However, in most of the empirical studies, the impact of the unemployment rate on new business entry has been found to be weakly significant or insignificant (Armington and Acs, 2002; Reynolds et al., 1994; Keeble and Walker 1994; and Brixy and Gortz, 2007). Data on 1-year lagged urban unemployment rate in regions (the average number of unemployed in a year divided by this year's labor force) will be included to investigate its effect.

As the samples are exhaustive geographical regions of a country whereby the economic situation in a region is likely influenced by the one of nearby regions, we need to isolate such spatial autocorrelation:

Spatial autocorrelation Spatial autocorrelation can cause the standard deviation of estimated coefficients to be underestimated (Brixy and Grotz, 2007). On one side, the effect of factors influencing new firm entry may not be limited to a region but may spill over adjacent regions. Thus, the mean of regional start-up rates in the regions neighboring each region is included as a measure of the spillover effect. It is expected to have a positive effect on the dependent variable, since nearer regions have more in common than those further away.

Appendix A presents the construction and descriptive statistics of the dependent and independent variables. Appendix B shows the pooled pair-wise correlation matrix of respective variables. Since variables are aggregate data at provincial level, so by nature of the construction, inter-correlations among them are quite high and significant. For instance, governmental investments are higher in those provinces being rich in entrepreneurial and innovative spirit; mean establishment size is certainly higher in those provinces having a larger share of population working in private sector; or technological resources are generally located in urban areas. However, we try to prevent the multicollinearity by transforming variables into growth and percentage share measures, and grouping independent variables into the regression in a way that is suggested by previous research.

\subsection{Model Development and Estimation Methods}

We propose two model treatments: the static model where only independent variables are 1 year-lagged; and the dynamic model where the lagged dependent variable is also included to isolate the effect of potential performance shock that may impede or stimulate new entries. In each model, we give two different specifications: the first one treats growth of incumbent firms as exogenous whereas the second measures diversification endogenously to take into account regional-specific characteristics that both stimulate firm entries and foster firm growth. However, since the covering period of the dataset from 2000 to 2008 was marked by a rather stable and fast economic development trend all over the country, the influence from economic cycle might be trivial to firm entries at the aggregate level. Indeed, the insignificant effect of the lagged dependent variable in the dynamic model justifies this conjecture, and indicates the superiority of the static model. Although endogeneity bias is commonly confronted in cross-sectional studies, it is less frequently considered a concern in panel data 
estimation. This is partially due to the conception that fixed effects estimation will eliminate most forms of unobserved heterogeneity (Verbeek and Nijman, 1992). However, Vella (1998) claims that certain forms of heterogeneity will not be eliminated with panel FE and RE models. The Durbin-Wu-Hausman test will be adopted to check whether endogeneity is likely to bias our estimation.

\subsubsection{The static model}

- Incumbent firm growth measured exogenously with regional-level characteristics: the error components model is adopted to introduce the regional and time effects in the error terms. Thus, spatial and temporal heterogeneity is incorporated into the model by its variance. Assuming that primary predictors selected for this study would take approximately one year to influence the process of new firm formation, all explanatory variables are taken one-year lag.

$$
\begin{aligned}
& \quad y_{i t}=\alpha+x_{i t-1} \beta+\gamma z_{i t,-1}+v_{i}+\varepsilon_{i t} \\
& (i=1,2, \ldots, n, t=1,2, \ldots, T)
\end{aligned}
$$

where $x_{i t-1}$ is the explanatory variable; $z_{i, t-1}$ is the vector of control variables; $v_{i}+\epsilon_{i z}$ is the residual, in which $v_{i}$ is the regional-specific residual; it differs between regions but, for any particular unit, its value is constant, $\epsilon_{i t}$ is the usual error term with the following assumptions

H1: $\epsilon_{i t}$ is uncorrelated with $v_{i}$ for all $i$ and $t$.

$\mathrm{H} 2: E\left(\epsilon_{i t}\right)=0$

$\mathrm{H} 3: E\left(\epsilon_{i t} \epsilon_{i^{\prime} t^{\prime}}\right)= \begin{cases}\sigma_{\varepsilon}^{2} & i=i^{r}, t=t^{r} \\ 0 & \text { otherwise }\end{cases}$

H4: $\epsilon_{i t} \sim N\left(0, \sigma_{\varepsilon}^{2}\right)$

- Tests for violations of assumptions:

+ Heteroskedasticity $(\mathrm{H} 3 \mathrm{a})$ : the problem of heteroskedasticity is more prevalent in cross-sectional data because they involve units and groups that are heterogeneous in nature. Two diagnostic tests, Breusch-Pagan's and White's test are employed to check for the presence of heteroskedasticity. It was indeed confirmed by both tests.

Table 1

Test for heteroskedasticity

\begin{tabular}{ll}
\hline \hline Breusch-Pagan test & Chi2 $(1)=1375.33$ \\
& Prob $>$ chi $2=0.000$ \\
White test & Chi2 $(90)=442.7472$ \\
& Prob $>$ chi $2=0.000$ \\
\hline
\end{tabular}

Thus, estimation with OLS is rejected, and the alternative estimation technique capable of correcting for heteroskedastic errors is "robust" regression method with standard errors corrected for heteroskedasticity by White's method.

+ Serial correlation in time-series data (H3b): The Wooldridge (2002) test for first-order autocorrelation in panel data is insignificant even at $10 \%$ level, which indicates the absence of first-order serial correlation. Serially correlated errors will give biased estimators by increasing variances of estimated coefficients. In this case, we can 
feel secured that net start-up rate as the dependent variable satisfies the assumption of no serial correlation.

Table 2

Wooldridge test for AR(1) serial correlation

\begin{tabular}{cl}
\hline \hline Serial correlation test & \multicolumn{1}{c}{ Start-up rate } \\
\hline \multirow{2}{*}{ Wooldridge first-order serial correlation test } & $\mathrm{F}(1,60)=0.877$ \\
& P-value $=0.3528$ \\
\hline \hline
\end{tabular}

- Estimation methods: Given the panel structure of the data, fixed-effects or randomeffects regression model can be used. According to Balestra (1995), as the nature of sample is closed and exhaustive, and the type of inference is with respect to effects that are in the sample, fixed effects regression is the natural candidate. Estimators are obtained from fixed effects regression of equation (1) as follows:

Define regional-specific means by $\bar{y}_{i}=\frac{1}{\tau} \sum_{t=1}^{T} y_{i t}$ and $\bar{x}_{i}=\frac{1}{T} \sum_{t=1}^{T} x_{i t}$ and deviations from these means as $y_{i}^{*}=y_{i}-\bar{y}_{i} l_{\tau}$ and $X_{i}^{*}=X_{i}-l_{T} \bar{x}_{i}^{*}$. Applying the within transformation, model (1) becomes

$$
y_{i}^{*}=X_{i}^{*} \beta_{i}+\epsilon_{i}^{*}(i=1,2, \ldots, n)
$$

The transformation eliminates totally unobserved regional-specific effects $v_{i}$ when $n$ is fixed (clearly the case) and $T$ goes to infinity, which results in efficient estimator

$$
\hat{\beta}_{W G}=\sum_{i=1}^{n}\left(X_{i}^{s} X_{i}^{*}\right)^{-1} X_{i}^{s t} y_{i}^{*}
$$

- Incumbent firm growth measured endogenously with regional-level characteristics: causality may run in both directions - from incumbent firm growth to new firm formation (as we mentioned from the above theoretical framework) or vice versa, i.e., it may be more efficient for larger firms to outsource to new neighboring firms some of their functions and are able to focus on their core production capabilities, which further enhance their growth. Thus, incumbent firm growth is likely to be correlated with controlled observable regional characteristics and unobserved characteristics absorbed in error terms.

The Durbin-Wu-Hausman test indicates the presence of endogeneity of incumbent firm growth although the presence is statistically significant at only $10 \%$ level. The test begins with the reduced form regression in which the assumed-endogenous incumbent firm growth is the dependent variable and all other observed exogenous regional-level characteristics are independent ones. Then residuals predicted from this regression are added into the structural form equation (1). The endogeneity problem is determined based on the significance of the residual coefficient.

Table 3

Test for Endogeneity

$\begin{array}{ll}\text { Durbin-Wu-Hausman test } & \mathrm{F}(1,415)=3.61 \\ & \mathrm{P} \text {-value }=0.0580\end{array}$

In case of endogeneity problem, instrumental variable (IV) two-stage least squares (2SLS) estimation is often adopted. However, since heteroskedasticity is present, we 
will apply the generalized method of moments (GMM) technique which is more efficient than the 2SLS (Baum and Schaffer, 2003). Following Arellano-Bond (1991), the instrument for the endogenous incumbent firm growth is its one-period lagged values. This makes the endogenous pre-determined and, hence, not correlated with the error term in equation (1). The results from GMM estimation applied for the static model are presented in Table 4

\subsubsection{The Dynamic Model$$
y_{i t}=\alpha y_{i z-1}+x_{i z-1} \beta+\gamma z_{i z-1}+v_{i}+\varepsilon_{i t}
$$$$
(i=1,2, \ldots, n ; t=1,2, \ldots, T)
$$

In equation (2), the 1-year lagged dependent variable is included. Several econometric problems may arise from estimating equation (2):

1. The diversification index $z_{i t}$ is assumed to be endogenous.

2. Time-invariant unobserved firm characteristics (fixed effects) $v_{i}$ may be correlated with diversification index $z_{i t}$ and control explanatory variables $X_{i t}$.

3. The panel dataset has a short time dimension $(T=8)$ and a larger number of regions $(n=61)$. Thus, the presence of the lagged dependent variable $y_{i z-1}$ would give rise to autocorrelation since it is correlated with fixed effects. It is, therefore, also treated as endogenous variable.

OLS and within group estimators of $\alpha_{,} \gamma, \beta$ are all inconsistent. To solve problem 1 and problem 2, one would usually use fixed-effects instrumental variables estimation (2SLS), but it depends on the availability and validity of exogenous instruments. Therefore, I decide to use the Arellano-Bond (1991) difference GMM estimator first proposed by Holtz-Eakin, Newey and Rosen (1988). Lagged levels of the endogenous regressor $z_{i *}$ are used as instruments, which rise over time. This makes the endogenous variable pre-determined and, hence, not correlated with the error term in equation (2). To cope with problem 2 (fixed effects), the difference GMM uses first-differences to transform equation (2) into:

$$
\Delta y_{i t}=\alpha \Delta y_{i t-1}+\gamma \Delta z_{i t}+\beta \Delta X_{i t}+\Delta \epsilon_{i t}
$$

By transforming the regressors by first differencing, the fixed regional-specific effect is removed, because it does not vary with time. Finally, to cope with problem 3, the Arellano-Bond estimator was designed for small-T and large-N panels. For the endogenous lagged dependent variable, the first-differenced lagged dependent variable is instrumented with its past levels.

\subsection{Model Estimation: Results and Interpretation}

Table 4 presents the estimation results for both static model and dynamic model. The static model adopts fixed-effects regression when incumbent firm growth is assumed exogenously; and GMM technique when it is assumed endogenously. The dynamic model applies differenced GMM estimation with two treatments: exogenous 
and endogenous incumbent firm growth. Overall, the static model with GMM treatment is the most preferable estimation, based on which results will be interpreted. The rationales for this claim are:

(i) The dataset has panel structure with a short time dimension and a larger number of observations

(ii) Heteroskedasticity tests indicate the presence of heteroskedasticity in the dataset

(iii)Wooldridge test for first order serial correlation indicates the absence of serial correlation.

(iv)Durbin-Wu-Hausman test for endogeneity indicates the presence of endogeneity of 'incumbent firm growth'

In general, the growth of incumbent firms in a particular region does have a stimulating effect on firm formation activities. The evidence is stronger when the sign of the associated regression coefficient is constant and the coefficient estimate is statistically significant across all model specifications (Levine and Renelt, 1992). This finding strongly supports both Hypothesis 1 and Hypothesis 2. Entrepreneurial opportunities emerging during the growth of incumbent firms motivate the competition among nascent entrepreneurs to "seize" and transform these opportunities into new firms. The parameters reduce their significance in both exogenous and endogenous treatment of the dynamic model. However, the insignificant one-year lagged 'incumbent firm growth' justifies the superiority of the findings from the static model with endogeneity treatment.

With respect to the control variables, five predictors - growth of GDP per capita, share of urban population, share of technical personnel, growth of monthly compensation per employee in SMEs, and governmental investment per capita- are found to have statistically significant effects on the dependent variable.

The indicator for the entrepreneurial climate in a region does not seem to influence entry. This is quite surprising for the case of an emerging economy like Vietnam in which we should expect the prevalence of micro-sized firms in the market is conducive to new firm formation. A number of comparable studies support the stimulating effect of entrepreneurial climate on firm entries (Guesnier, 1994; Keeble and Walker, 1994; Hart and Gudgin, 1994; Fotopoulos and Spence, 1999). Two reasons can be submitted to explain this apaprently puzzling finding: either nascent entrepreneurs themselves are not motivated to participate into a market of intense competition among newlyestablished firms or "the revolving door" effect of the market is so efficient that a significant number of new entries in the previous year will immediately cause an equivalent number of exits among both unprofitable incumbents and "bad entries" (Santarelli and Vivarelli, 2007), which may subsequently produce negative net start-ups in the current year.

The fixed-effects regression when the share of micro-sized firms of the current year is used instead of the one-year lagged one indeed justifies the latter explanation. The share of micro-sized firms has a positive relationship with net entry in the same year: the greater the dominance of micro-firms the larger the number of new entries in the same year, which is able to more than compensate exits. 
Table 4

Determinants of New Business Formation

\begin{tabular}{|c|c|c|c|c|c|c|c|c|}
\hline & \multicolumn{8}{|c|}{ Regional net entry rate - Heteroskedasticity-adjusted models } \\
\hline & \multirow{3}{*}{\multicolumn{4}{|c|}{\begin{tabular}{cc} 
& \multicolumn{2}{c}{ Static Model } \\
$y_{i t}=\alpha+x_{i, t-1} \beta+\gamma z_{i, t-1}+v_{i}+z_{i t}$ \\
FE
\end{tabular}}} & \multirow{2}{*}{\multicolumn{4}{|c|}{$\begin{array}{c}\text { Dynamic Model } \\
y_{i t}=a y_{i t-1}+x_{i, t-1} \beta+\gamma z_{i, t-1}+v_{i}+\varepsilon_{i t}\end{array}$}} \\
\hline & & & & & & & & \\
\hline & & & & & \multicolumn{2}{|c|}{ GMM exogenous } & \multicolumn{2}{|c|}{ GMM endogenous } \\
\hline & $(1)$ & (2) & (3) & (4) & $(5)$ & (6) & (7) & $(8)$ \\
\hline Intercept & $\begin{array}{l}-0.172 \\
(0.093)\end{array}$ & $\begin{array}{l}-0.189^{*} \\
(0.096)\end{array}$ & $\begin{array}{l}-0.0397 \\
(0.026)\end{array}$ & $\begin{array}{c}-0.114 * * \\
(0.042)\end{array}$ & $\begin{array}{l}0.0116 \\
(0.013)\end{array}$ & $\begin{array}{c}0.0112 \\
(0.0145)\end{array}$ & $\begin{array}{l}0.0148 \\
(0.009)\end{array}$ & $\begin{array}{c}0.0128 \\
(0.0114)\end{array}$ \\
\hline Net entry rate $(\mathrm{t}-1)$ & & & & & $\begin{array}{l}-0.129 \\
(0.115)\end{array}$ & $\begin{array}{l}-0.147 \\
(0.118)\end{array}$ & $\begin{array}{l}-0.212 \\
(0.123)\end{array}$ & $\begin{array}{l}-0.232 \\
(0.13)\end{array}$ \\
\hline $\begin{array}{l}\text { Growth of incumbent } \\
\text { firms }(t-1)\end{array}$ & $\begin{array}{l}0.019^{*} \\
(0.009)\end{array}$ & $\begin{array}{l}0.019^{*} \\
(0.009)\end{array}$ & $\begin{array}{c}0.0184^{*} \\
(0.009)\end{array}$ & $\begin{array}{c}0.0175^{*} \\
(0.009)\end{array}$ & $\begin{array}{l}0.014^{*} \\
(0.008)\end{array}$ & $\begin{array}{l}0.014^{*} \\
(0.008)\end{array}$ & $\begin{array}{l}0.0226 \\
(0.014)\end{array}$ & $\begin{array}{c}0.024 \\
(0.015)\end{array}$ \\
\hline \multicolumn{9}{|c|}{ Entrepreneurial climate } \\
\hline $\begin{array}{l}\text { Share of micro- } \\
\text { sized firms (t-1) }\end{array}$ & $\begin{array}{l}-0.028 \\
(0.081)\end{array}$ & $\begin{array}{l}-0.026 \\
(0.082)\end{array}$ & $\begin{array}{l}-0.015 \\
(0.03)\end{array}$ & $\begin{array}{l}-0.009 \\
(0.033)\end{array}$ & $\begin{array}{c}0.179 \\
(0.111)\end{array}$ & $\begin{array}{c}0.004 \\
(0.109)\end{array}$ & $\begin{array}{c}0.043 \\
(0.114)\end{array}$ & $\begin{array}{l}0.0218 \\
(0.113)\end{array}$ \\
\hline $\begin{array}{l}\text { Share of } \\
\text { enterprises' labor } \\
\text { force(t-1) }\end{array}$ & - & $\begin{array}{c}0.281 \\
(0.543)\end{array}$ & - & $\begin{array}{c}0.203 \\
(0.407)\end{array}$ & ( & $\begin{array}{c}0.6699 * \\
(0.302)\end{array}$ & ( & $\begin{array}{l}0.987 * \\
(0.428)\end{array}$ \\
\hline \multicolumn{9}{|c|}{ Entrepreneurial demand } \\
\hline $\begin{array}{l}\text { Growth of GDP } \\
\text { per capita (t-1) }\end{array}$ & $\begin{array}{l}0.067 * * \\
(0.0035)\end{array}$ & $\begin{array}{c}0.058^{* *} \\
(0.005)\end{array}$ & $\begin{array}{l}0.067 * * \\
(0.0032)\end{array}$ & $\begin{array}{l}0.054 * * \\
(0.0067)\end{array}$ & $\begin{array}{c}0.068 * * \\
(0.006)\end{array}$ & $\begin{array}{l}0.0597 * * \\
(0.0084)\end{array}$ & $\begin{array}{c}0.065 * * \\
(0.006)\end{array}$ & $\begin{array}{c}0.0599 * * \\
(0.0081)\end{array}$ \\
\hline \multicolumn{9}{|l|}{ Agglomeration } \\
\hline $\begin{array}{l}\text { Growth of } \\
\text { population } \\
\text { density(t-1) }\end{array}$ & $\begin{array}{c}0.0339 \\
(0.0748)\end{array}$ & $\begin{array}{c}0.031 \\
(0.081)\end{array}$ & $\begin{array}{l}-0.225 \\
(0.155)\end{array}$ & $\begin{array}{l}-0.194 \\
(0.138)\end{array}$ & $\begin{array}{l}-0.015 \\
(0.054)\end{array}$ & $\begin{array}{l}0.0006 \\
(0.055)\end{array}$ & $\begin{array}{l}-0.022 \\
(0.049)\end{array}$ & $\begin{array}{l}-0.0125 \\
(0.0493)\end{array}$ \\
\hline $\begin{array}{l}\text { Share of urban } \\
\text { population(t-1) }\end{array}$ & $\begin{array}{c}0.504 \\
(0.305)\end{array}$ & $\begin{array}{c}0.499 \\
(0.312)\end{array}$ & $\begin{array}{l}0.211^{* *} \\
(0.082)\end{array}$ & $\begin{array}{l}0.217 * * \\
(0.0788)\end{array}$ & $\begin{array}{c}0.243 \\
(0.422)\end{array}$ & $\begin{array}{c}0.299 \\
(0.433)\end{array}$ & $\begin{array}{c}0.177 \\
(0.387)\end{array}$ & $\begin{array}{c}0.229 \\
(0.385)\end{array}$ \\
\hline \multicolumn{9}{|l|}{ Market structure } \\
\hline $\begin{array}{l}\text { Mean } \\
\text { establishment size } \\
\text { MES (t-1) }\end{array}$ & $\begin{array}{l}0.0009 * \\
(0.0004)\end{array}$ & $\begin{array}{l}0.0009 * \\
(0.0004)\end{array}$ & $\begin{array}{l}0.00005 \\
(0.0003)\end{array}$ & $\begin{array}{l}0.00004 \\
(0.0002)\end{array}$ & $\begin{array}{c}0.0033 * * \\
(0.001)\end{array}$ & $\begin{array}{l}0.0032 * * \\
(0.0011)\end{array}$ & $\begin{array}{c}0.0033 * * \\
(0.0011)\end{array}$ & $\begin{array}{c}0.0029 * \\
(0.001)\end{array}$ \\
\hline \multicolumn{9}{|l|}{ Market innovativeness } \\
\hline $\begin{array}{l}\text { Share of } \\
\text { technical/R\&D } \\
\text { personnel }(\mathrm{t}-1)\end{array}$ & $\begin{array}{l}6.655^{*} \\
(3.224)\end{array}$ & $\begin{array}{l}6.575^{*} \\
(3.396)\end{array}$ & $\begin{array}{c}9.775^{* *} \\
(1.64)\end{array}$ & $\begin{array}{c}10.088 * * \\
(1.972)\end{array}$ & $\begin{array}{l}8.125^{*} \\
(3.577)\end{array}$ & $\begin{array}{l}7.837 * \\
(3.628)\end{array}$ & $\begin{array}{l}7.674 * \\
(3.285)\end{array}$ & $\begin{array}{l}7.13 * \\
(3.33)\end{array}$ \\
\hline \multicolumn{9}{|l|}{ Income effect } \\
\hline $\begin{array}{l}\text { Growth of } \\
\text { monthly } \\
\text { compensation per } \\
\text { employee }(\mathrm{t}-1)\end{array}$ & - & $\begin{array}{c}0.0495 * \\
(0.026)\end{array}$ & - & $\begin{array}{l}0.0692^{*} \\
(0.0318)\end{array}$ & - & $\begin{array}{c}0.042 \\
(0.034)\end{array}$ & - & $\begin{array}{c}0.034 \\
(0.037)\end{array}$ \\
\hline \multicolumn{9}{|l|}{ Unemployment effect } \\
\hline $\begin{array}{l}\text { Unemployment } \\
\text { rate }(\mathrm{t}-1)\end{array}$ & - & $\begin{array}{l}-0.0002 \\
(0.005)\end{array}$ & - & $\begin{array}{c}0.009 \\
(0.006)\end{array}$ & - & $\begin{array}{c}0.0041 \\
(0.0084)\end{array}$ & - & $\begin{array}{c}0.0074 \\
(0.0103)\end{array}$ \\
\hline \multicolumn{9}{|c|}{ Regional economic environment } \\
\hline $\begin{array}{l}\text { Public investment } \\
\text { per capita (t-1) }\end{array}$ & $\begin{array}{c}0.022 * * \\
(0.008)\end{array}$ & $\begin{array}{l}0.0188^{*} \\
(0.0086)\end{array}$ & $\begin{array}{l}0.022 * * \\
(0.008)\end{array}$ & $\begin{array}{c}0.0257 * * \\
(0.009)\end{array}$ & $\begin{array}{l}0.0187 * \\
(0.0103)\end{array}$ & $\begin{array}{c}0.0138 \\
(0.0104)\end{array}$ & $\begin{array}{c}0.0156 \\
(0.0107)\end{array}$ & $\begin{array}{c}0.009 \\
(0.011)\end{array}$ \\
\hline \multicolumn{9}{|c|}{ Spatial autocorrelation control } \\
\hline $\begin{array}{l}\text { Spatial spillover } \\
\text { effects }\end{array}$ & $\begin{array}{c}0.496 * * \\
(0.109) \\
\end{array}$ & $\begin{array}{c}0.492 * * \\
(0.109) \\
\end{array}$ & $\begin{array}{c}0.287 * * \\
(0.075)\end{array}$ & $\begin{array}{c}0.284 * * \\
(0.076) \\
\end{array}$ & $\begin{array}{l}0.549^{*} \\
(0.254) \\
\end{array}$ & $\begin{array}{l}0.551 * \\
(0.262)\end{array}$ & $\begin{array}{l}0.537 * \\
(0.218)\end{array}$ & $\begin{array}{l}0.543^{*} \\
(0.231) \\
\end{array}$ \\
\hline F-value & $209.21 * *$ & $157.56 * *$ & $184.52 * *$ & $139.80 * *$ & & & & \\
\hline Hansen J statistic & & & 0.096 & 0.183 & & & & \\
\hline $\begin{array}{l}\text { Arellano-Bond test fo } \\
\text { autocovariance of ord }\end{array}$ & & & & & $-3.13 * *$ & $-3.39 * *$ & $-2.39 *$ & $-2.38 *$ \\
\hline $\begin{array}{l}\text { Arellano-Bond test fo } \\
\text { autocovariance of ord }\end{array}$ & & & & & 0.09 & -0.07 & -0.42 & -0.57 \\
\hline Observations & 488 & 488 & 427 & 427 & 366 & 366 & 366 & 366 \\
\hline
\end{tabular}

Note: ** significant at 1\%-level; * significant at 5\%-level; standard errors are in parentheses 
But, consistent with the "creative destruction" mechanism proposed by Schumpeter (1934), this might lead to a negative relationship with net entry of the next year: entry of a great number of new firms creates a highly competitive and turbulent market such that an equivalently large number of firms, either "bad entries" or stagnating incumbents, are forced to exit. The positive, though statistically insignificant, effect of the share of enterprises' labor force in the total regional labor supply, on the other hand, indicates that the dominance of a strong private sector in the market is favorable to start-up activities. This partially confirms the "incubator theory", assuming that people employed in smaller firms are more prone to set up a business of their own. It is likely that working in smaller firms allows employees to have deeper and broader insights into how to run a firm, while working in larger firms enables them to be more specialized. Since nearly $95 \%$ of enterprises in Vietnam are household businesses with household proprietorship (Rand and Tarp, 2007), a large fraction of the labor force in private sector are self-employed individuals. Thus, it is fair to say that the higher the share of labor force working in the private sector the higher entrepreneurial spirit the region reflects.

The positive and significant coefficient of the growth of the regional gross domestic income per capita variable indicates that net entry is higher where gross value added per person is higher. The effect is quite strong no matter what methodological treatment is applied, which suggests that personal wealth is crucially important for founding a new manufacturing firm given the fact that the majority of set-up capital comes from owners' income and savings.

For mean establishment size, consistent with Sutaria and Hicks (2004), the estimation shows a positive and significant relationship with net entry. The dominance of larger firms will give abundant outsourcing opportunities to smaller neighboring firms in producing specialty goods and services, and hence, generally stimulates firm entries. However, this result may differ across industries, since entry barriers industries characterized by economies of scale and high labor or capital intensiveness are more severe than those in modern high-tech industries.

For a potential entrepreneur currently working as paid employee, the opportunity cost of establishing a new firm corresponds to his/her monthly salary or compensation. However, in Vietnam, since it is quite common that entrepreneurs maintain both their salary-paid job and self-employed business, and since most of investment capital for their own business comes from savings and salary, compensation growth actually imposes a stimulating effect on new firm formation. The higher the salary increases overtime, the sooner the employee save enough capital for setting up their own business. Besides, the push effect from regional economic environment through public investments on entry in each province is quite strong. Other things held constant, people in a province being endowed with more state-invested capital are more likely to be selfemployed than equally able people in another province with less state-invested capital.

The effect of agglomeration proxied by the share of urban population in the overall provincial population is positive and statistically significant. The estimation does support the urban incubator theory that metropolitan areas and urban centers are nurseries of new firms. However, since the the beginning of the process of economic reforms initiated in 1986 with the purpose of creating a "socialist-oriented market economy" (known as doi moi), Vietnam has witnessed a rapid urbanization and industrialization, ultimately leading to the conversion of large rural areads into metropolitan areas and urban centers; these reforms have forced thousands of farmer households to be in the transition from traditional agricultural and rural-based economic activities to urbanized livelihoods. The newly-born urban areas have in most cases 
worked as a "revolving door" to eliminate "entry mistakes" (Santarelli and Vivarelli, 2007), rather than as an incubator of new successful firms.

Our findings of a non-statistically significant relationship between unemployment and entry are not at odds with previous empirical studies reporting contradictory evidences with respect to such a relationship (cf. Santarelli et al., 2009). In this respect, it is worth noting that the period from 2000 to 2008 marks both high economic growth and poor labor market conditions in Vietnam. On one hand, the country has benefitted from the launch of Enterprise Law in 2000, creating a firmer legal basis for the development of the private sector, and from the official approval to hold World Trade Organization membership. On the other hand, since high economic growth attracts people to migrate to big cities in large number, it is inevitable that while unemployment increases quickly in urban areas, job opportunities are redundant in rural areas. Thus, the insignificant relationship between unemployment rate and net entry may depend upon the interplay of two coexisting forces, i.e. high unemployment rate shows a poor functioning market that hampers start-up efforts and high economic growth stimulates new firm formation to satisfy increasing consumers' demands.

Finally, we find statistically significant spatial autocorrelation among neighboring regions across all methodological treatments. As expected, neighboring regions share more common features than those further away.

\section{Conclusions}

The main finding in this paper is that, in 61 Vietnamese provinces from 2000 to 2008 , net entry is strongly affected by the performance of incumbent firms. Incumbents' growth creates changes in the existing production system, in this way generating new entrepreneurial opportunities not only for themselves but also for the whole society. Due to their inflexible administrative organization and path-dependent development, incumbent firms are constrained to pursuit only a relatively small fraction of the opportunities that they create. As a consequence, a significant number of entrepreneurial opportunities are left underexploited, which might be taken by nascent entrepreneurs.

There are two main limitations to our study, which open up directions for future research. First, we use net entry as a proxy of regional firm formation activities. Since the "revolving door effect" is quite strong in the Vietnamese regions, a significant number of new entries in previous year are likely to cause an almost equivalent number of exits in the subsequent year, in relation to which one might therefore find negative net entry. Second, we conduct our analysis at a regionally aggregated level, without taking into account the effect of industry-specific factors on new business formation and net entry. Should new data be released, we will give explicit consideration to the issues of gross entry, taken as the most reliable proxy of entrepreneurship capital (Acs et al., 2009), and of industry-specific determinants of new firm formation (Carree et al., 2008).

As a final robust test to justify our choice of 3-year-old incumbent firms for the analysis, we apply the same methodological treatments to 5-year-old incumbent firms and total firms in a region. Regression results are presented in Appendix C. In general, we can observe two key findings: (i) growth of 5-year-old incumbent firm sales has stronger statistical stimulating effect on new entries, which firmly supports our hypothesis; (ii) growth of sales of all existing firms does not have any impact on entry activities. There is simply no relation between them. Other controlling indicators have equivalently comparable effects. Therefore, we could be guaranteed that sales performance of incumbent firms in a region strongly impedes or improves the 
entrepreneurship capital of that region, i.e. the capacity of a region to generate the startup of new firms, rather than just the effect of an economic cycle. 
Appendix A: Dependent variables and Independent variables.

\begin{tabular}{|c|c|c|c|c|c|c|c|c|c|}
\hline Categories & Indicators & Variables & Measure & Obs. & Mean & Std.Dev. & Min & $\operatorname{Max}$ & $\begin{array}{c}\text { Expected } \\
\text { relationship }\end{array}$ \\
\hline $\begin{array}{l}\text { Dependent } \\
\text { variable }\end{array}$ & $\begin{array}{l}\text { New business } \\
\text { formation }\end{array}$ & Net entry rates & $\begin{array}{l}\text { The ratio of number of new firms per } 1000 \\
\text { persons in population }\end{array}$ & 488 & 0.175 & 0.253 & -0.36 & 2.842 & \\
\hline $\begin{array}{l}\text { Explanatory } \\
\text { variable }\end{array}$ & $\begin{array}{l}\text { Growth of } \\
\text { incumbent firms }\end{array}$ & Incumbent growth & $\begin{array}{l}\text { The annual percentage change in revenues } \\
\text { of existing incumbent firms (over } 3 \text { years } \\
\text { old) }\end{array}$ & 488 & 0.841 & 1.831 & -0.51 & 31.75 & Positive \\
\hline \multirow{3}{*}{$\begin{array}{l}\text { Control vars: } \\
\text { Entrepreneurial } \\
\text { opportunities } \\
\text { created from } \\
\text { Regional } \\
\text { Entrepreneurial } \\
\text { indicators }\end{array}$} & \multirow{2}{*}{$\begin{array}{l}\text { Entrepreneurial } \\
\text { climate }\end{array}$} & $\begin{array}{l}\text { The share of micro- } \\
\text { sized firms }\end{array}$ & $\begin{array}{l}\text { The percentage share of micro-sized firms in } \\
\text { the total number of enterprises in the region }\end{array}$ & 488 & 0.451 & 0.16 & 0.61 & 0.97 & Positive \\
\hline & & $\begin{array}{l}\text { Labor force in private } \\
\text { sector }\end{array}$ & $\begin{array}{l}\text { The percentage share of enterprises' labor } \\
\text { force in the total regional population }\end{array}$ & 488 & 0.048 & 0.059 & 0.007 & 0.466 & Positive \\
\hline & $\begin{array}{l}\text { Entrepreneurial } \\
\text { demand }\end{array}$ & $\begin{array}{l}\text { Growth of regional } \\
\text { GDP per capita }\end{array}$ & $\begin{array}{l}\text { The annual percentage change in regional } \\
\text { gross domestic product per capita at } \\
\text { comparative price of } 1994\end{array}$ & 488 & 0.127 & 0.596 & -0.12 & 13.19 & Positive \\
\hline \multirow{5}{*}{$\begin{array}{l}\text { Control vars: } \\
\text { Entrepreneurial } \\
\text { opportunities } \\
\text { created from } \\
\text { Regional } \\
\text { Structural } \\
\text { indicators }\end{array}$} & \multirow{2}{*}{ Agglomeration } & $\begin{array}{l}\text { Growth of population } \\
\text { density }\end{array}$ & $\begin{array}{l}\text { The annual percentage change in regional } \\
\text { population density }\end{array}$ & 549 & 0.009 & 0.032 & -0.49 & 0.086 & Positive \\
\hline & & Urbanization & $\begin{array}{l}\text { The percentage share of urban population in } \\
\text { the total regional population }\end{array}$ & 549 & 0.225 & 0.156 & 0.058 & 0.853 & Positive \\
\hline & Market structure & $\begin{array}{l}\text { Mean Establishment } \\
\text { Size (MES) }\end{array}$ & $\begin{array}{l}\text { The mean number of employees per } \\
\text { establishment }\end{array}$ & 488 & 57.97 & 30.77 & 14 & 226 & Positive \\
\hline & $\begin{array}{c}\text { Education } \\
\text { background }\end{array}$ & Innovativeness & $\begin{array}{l}\text { The percentage share of technical and } R \& D \\
\text { personnel in the total regional labor force }\end{array}$ & 488 & 0.005 & 0.0147 & .00006 & 0.131 & Positive \\
\hline & $\begin{array}{c}\text { Reg. economic } \\
\text { environment }\end{array}$ & Public investment & $\begin{array}{l}\text { State-invested capital per a person at } \\
\text { working age }\end{array}$ & 488 & 2.602 & 2.072 & 0.186 & 20.367 & Positive \\
\hline \multirow{2}{*}{$\begin{array}{l}\text { Control vars.: } \\
\text { other individual } \\
\text { motivational } \\
\text { factors }\end{array}$} & $\begin{array}{l}\text { Unemployment } \\
\text { effect }\end{array}$ & $\begin{array}{l}\text { Regional urban } \\
\text { unemployment }\end{array}$ & Annual urban unemployment rate & 488 & 5.49 & 1.13 & 2.28 & 8.96 & Indeterminate \\
\hline & Income effect & $\begin{array}{l}\text { Compensation in } \\
\text { private sector }\end{array}$ & $\begin{array}{l}\text { Growth of average compensation per month } \\
\text { of employees working in SMEs }\end{array}$ & 488 & 0.285 & 0.187 & -0.275 & 2.672 & Negative \\
\hline $\begin{array}{l}\text { Control vars: } \\
\text { Spatial } \\
\text { autocorrelation } \\
\end{array}$ & \multicolumn{2}{|l|}{ Spillover effects } & $\begin{array}{l}\text { Mean of regional start-up rates in the } \\
\text { regions neighboring each region }\end{array}$ & 488 & 0.149 & 0.115 & -0.045 & 0.665 & Indeterminate \\
\hline
\end{tabular}


Appendix B: Correlation Matrix of Dependent variables and Independent variables.

\begin{tabular}{|c|c|c|c|c|c|c|c|c|c|c|c|c|}
\hline & $\begin{array}{l}\text { Net start- } \\
\text { up }\end{array}$ & $\begin{array}{l}\text { Incum. } \\
\text { Growth }\end{array}$ & $\begin{array}{c}\text { Micro } \\
\text { share }\end{array}$ & $\begin{array}{l}\text { Enter } \\
\text { labor }\end{array}$ & $\begin{array}{l}\text { GDP. } \\
\text { Capita }\end{array}$ & $\begin{array}{l}\text { Popul. } \\
\text { Density }\end{array}$ & $\begin{array}{l}\text { Urban } \\
\text { popu. }\end{array}$ & MES & $\begin{array}{l}\text { Tech. } \\
\text { employ }\end{array}$ & Compen. & Unemploy. & $\begin{array}{l}\text { Public } \\
\text { invest. }\end{array}$ \\
\hline $\begin{array}{l}\text { Net start- } \\
\text { up }\end{array}$ & 1.0000 & & & & & & & & & & & \\
\hline $\begin{array}{l}\text { Incum. } \\
\text { Growth }\end{array}$ & $0.578^{*}$ & 1.0000 & & & & & & & & & & \\
\hline $\begin{array}{c}\text { Micro } \\
\text { share }\end{array}$ & 0.0244 & 0.0399 & 1.0000 & & & & & & & & & \\
\hline Enter labor & $0.6800 *$ & $0.3601 *$ & -0.0548 & 1.0000 & & & & & & & & \\
\hline $\begin{array}{l}\text { GDP } \\
\text { capita }\end{array}$ & $0.1957^{*}$ & 0.0853 & -0.0041 & -0.0079 & 1.0000 & & & & & & & \\
\hline $\begin{array}{l}\text { Popul. } \\
\text { Density }\end{array}$ & $0.1214^{*}$ & 0.0852 & -0.0056 & $0.2658 *$ & 0.0106 & 1.0000 & & & & & & \\
\hline $\begin{array}{l}\text { Urban } \\
\text { popul. }\end{array}$ & $0.5615^{*}$ & $0.3360^{*}$ & $0.1871 *$ & $0.5980^{*}$ & -0.0290 & $0.1506^{*}$ & 1.0000 & & & & & \\
\hline MES & 0.1161 & 0.0304 & $-0.4950 *$ & $0.4575^{*}$ & -0.0146 & $0.1903 *$ & $0.1654^{*}$ & 1.0000 & & & & \\
\hline $\begin{array}{c}\text { Tech } \\
\text { employ. }\end{array}$ & $0.8359 *$ & $0.5105^{*}$ & 0.0516 & $0.7487 *$ & 0.0303 & $0.1620^{*}$ & $0.5549 *$ & 0.1154 & 1.0000 & & & \\
\hline Compen & $0.2006^{*}$ & $0.1321 *$ & -0.0995 & 0.0312 & $0.5859 *$ & 0.0016 & -0.1043 & -0.0010 & 0.0512 & 1.0000 & & \\
\hline Unemploy. & 0.0445 & -0.0129 & 0.0031 & 0.0712 & -0.0100 & 0.0274 & $0.1587^{*}$ & $0.2767 *$ & 0.0962 & $-0.1288^{*}$ & 1.0000 & \\
\hline $\begin{array}{l}\text { Public } \\
\text { invest. }\end{array}$ & $0.6813^{*}$ & $0.3474^{*}$ & 0.0331 & $0.7932 *$ & $0.1737 *$ & $0.1297^{*}$ & $0.4582 *$ & 0.0606 & $0.7652 *$ & 0.0936 & $-0.2471^{*}$ & 1.0000 \\
\hline
\end{tabular}

Note: *: significant at $1 \%$ level 
Appendix C

Determinants of New Business Formation

\begin{tabular}{|c|c|c|c|c|c|c|c|c|}
\hline & \multicolumn{8}{|c|}{ Regional net entry rate - Heteroskedasticity-adjusted static models } \\
\hline & \multicolumn{4}{|c|}{ 5-year-old incumbent firms } & \multicolumn{4}{|c|}{ Existing firms } \\
\hline & \multicolumn{2}{|c|}{ FE } & \multicolumn{2}{|c|}{ GMM } & \multicolumn{2}{|c|}{ FE } & \multicolumn{2}{|c|}{ GMM } \\
\hline & $(9)$ & $(10)$ & $(11)$ & $(12)$ & $(13)$ & (14) & $(15)$ & $(16)$ \\
\hline Intercept & $\begin{array}{l}-0.216^{*} \\
(0.096)\end{array}$ & $\begin{array}{l}-0.233^{*} \\
(0.099)\end{array}$ & $\begin{array}{l}-0.086^{*} \\
(0.037)\end{array}$ & $\begin{array}{c}-0.149 * * \\
(0.042)\end{array}$ & $\begin{array}{l}-0.165 \\
(0.097)\end{array}$ & $\begin{array}{c}-0.192 \\
(0.1009)\end{array}$ & $\begin{array}{l}-0.069 * \\
(0.027)\end{array}$ & $\begin{array}{c}-0.116^{* *} \\
(0.043)\end{array}$ \\
\hline Growth of firms (t-1) & $\begin{array}{l}0.008^{*} \\
(0.004)\end{array}$ & $\begin{array}{l}0.007 * \\
(0.003)\end{array}$ & $\begin{array}{l}0.008^{*} \\
(0.004)\end{array}$ & $\begin{array}{l}0.007^{*} \\
(0.004)\end{array}$ & $\begin{array}{c}0.043 \\
(0.031)\end{array}$ & $\begin{array}{c}0.0315 \\
(0.0341)\end{array}$ & $\begin{array}{c}0.038 \\
(0.036)\end{array}$ & $\begin{array}{c}0.015 \\
(0.039)\end{array}$ \\
\hline \multicolumn{9}{|c|}{ Entrepreneurial climate } \\
\hline $\begin{array}{l}\text { Share of micro- } \\
\text { sized firms (t-1) }\end{array}$ & $\begin{array}{l}-0.016 \\
(0.081)\end{array}$ & $\begin{array}{l}-0.016 \\
(0.083)\end{array}$ & $\begin{array}{l}-0.016 \\
(0.03)\end{array}$ & $\begin{array}{r}-0.0135 \\
(0.041)\end{array}$ & $\begin{array}{l}-0.0305 \\
(0.085)\end{array}$ & $\begin{array}{r}-0.0304 \\
(0.088)\end{array}$ & $\begin{array}{l}0.0102 \\
(0.033)\end{array}$ & $\begin{array}{c}0.031 \\
(0.039)\end{array}$ \\
\hline $\begin{array}{l}\text { Share of } \\
\text { enterprises' labor } \\
\text { force(t-1) }\end{array}$ & - & $\begin{array}{c}0.173 \\
(0.537)\end{array}$ & - & $\begin{array}{c}0.179 \\
(0.436)\end{array}$ & - & $\begin{array}{c}0.18 \\
(0.56)\end{array}$ & - & $\begin{array}{c}0.414 \\
(0.434)\end{array}$ \\
\hline \multicolumn{9}{|c|}{ Entrepreneurial demand } \\
\hline $\begin{array}{l}\text { Growth of GDP } \\
\text { per capita (t-1) }\end{array}$ & $\begin{array}{c}0.0703 * * \\
(0.0039)\end{array}$ & $\begin{array}{c}0.062 * * \\
(0.006)\end{array}$ & $\begin{array}{l}0.07 * * \\
(0.003)\end{array}$ & $\begin{array}{c}0.059 * * \\
(0.006)\end{array}$ & $\begin{array}{c}0.069 * * \\
(0.004)\end{array}$ & $\begin{array}{l}0.059 * * \\
(0.0064)\end{array}$ & $\begin{array}{c}0.069 * * \\
(0.003)\end{array}$ & $\begin{array}{r}0.061 * * \\
(0.006)\end{array}$ \\
\hline \multicolumn{9}{|l|}{ Agglomeration } \\
\hline $\begin{array}{l}\text { Growth of } \\
\text { population } \\
\text { density(t-1) }\end{array}$ & $\begin{array}{l}0.0494 \\
(0.077)\end{array}$ & $\begin{array}{c}0.047 \\
(0.083)\end{array}$ & $\begin{array}{l}-0.192 \\
(0.149)\end{array}$ & $\begin{array}{l}-0.167 \\
(0.131)\end{array}$ & $\begin{array}{c}0.032 \\
(0.081)\end{array}$ & $\begin{array}{c}0.036 \\
(0.086)\end{array}$ & $\begin{array}{l}-0.189 \\
(0.159)\end{array}$ & $\begin{array}{r}-0.152 \\
(0.14)\end{array}$ \\
\hline $\begin{array}{l}\text { Share of urban } \\
\text { population(t-1) }\end{array}$ & $\begin{array}{c}0.555 \\
(0.325)\end{array}$ & $\begin{array}{c}0.557 \\
(0.333)\end{array}$ & $\begin{array}{c}0.238^{*} \\
(0.119)\end{array}$ & $\begin{array}{l}0.254 * \\
(0.111)\end{array}$ & $\begin{array}{c}0.478 \\
(0.323)\end{array}$ & $\begin{array}{c}0.001 \\
(0.004)\end{array}$ & $\begin{array}{c}0.174 \\
(0.121)\end{array}$ & $\begin{array}{c}0.168 \\
(0.109)\end{array}$ \\
\hline \multicolumn{9}{|l|}{ Market structure } \\
\hline $\begin{array}{l}\text { Mean } \\
\text { establishment size } \\
\text { MES (t-1) }\end{array}$ & $\begin{array}{l}0.0007 * \\
(0.0004)\end{array}$ & $\begin{array}{l}0.0008 * \\
(0.0004)\end{array}$ & $\begin{array}{l}0.00004 \\
(0.0003)\end{array}$ & $\begin{array}{l}0.00001 \\
(0.0003)\end{array}$ & $\begin{array}{l}0.0008 * \\
(0.0004)\end{array}$ & $\begin{array}{l}0.0008 * \\
(0.0004)\end{array}$ & $\begin{array}{c}0.0001 \\
(0.0002)\end{array}$ & $\begin{array}{c}0.0004 \\
(0.0003)\end{array}$ \\
\hline \multicolumn{9}{|l|}{ Market innovativeness } \\
\hline $\begin{array}{l}\text { Share of } \\
\text { technical/R\&D } \\
\text { personnel (t-1) }\end{array}$ & $\begin{array}{l}7.527^{*} \\
(3.057)\end{array}$ & $\begin{array}{l}7.505^{*} \\
(3.19)\end{array}$ & $\begin{array}{c}10.318 * * \\
(1.996)\end{array}$ & $\begin{array}{c}10.367 * * \\
(2.334)\end{array}$ & $\begin{array}{c}8.009 * * \\
(3.152)\end{array}$ & $\begin{array}{l}7.96^{*} \\
(3.28)\end{array}$ & $\begin{array}{c}11.43 * * \\
(1.93)\end{array}$ & $\begin{array}{c}12.22 * * \\
(2.19)\end{array}$ \\
\hline \multicolumn{9}{|l|}{ Income effect } \\
\hline $\begin{array}{l}\text { Growth of } \\
\text { monthly } \\
\text { compensation per } \\
\text { employee (t-1) }\end{array}$ & - & $\begin{array}{l}0.045^{*} \\
(0.026)\end{array}$ & - & $\begin{array}{l}0.0596^{*} \\
(0.0336)\end{array}$ & - & $\begin{array}{l}0.055^{*} \\
(0.028)\end{array}$ & - & $\begin{array}{c}0.035 \\
(0.032)\end{array}$ \\
\hline \multicolumn{9}{|l|}{ Unemployment effect } \\
\hline $\begin{array}{l}\text { Unemployment } \\
\text { rate }(t-1)\end{array}$ & - & $\begin{array}{l}-0.0006 \\
(0.004)\end{array}$ & - & $\begin{array}{c}0.009 \\
(0.007)\end{array}$ & - & $\begin{array}{c}0.001 \\
(0.004)\end{array}$ & - & $\begin{array}{c}0.003 \\
(0.006)\end{array}$ \\
\hline \multicolumn{9}{|c|}{ Regional economic environment } \\
\hline $\begin{array}{l}\text { Public investment } \\
\text { per capita }(\mathrm{t}-1)\end{array}$ & $\begin{array}{c}0.0207 * * \\
(0.008)\end{array}$ & $\begin{array}{c}0.0186^{*} \\
(0.009)\end{array}$ & $\begin{array}{l}0.021^{*} \\
(0.009)\end{array}$ & $\begin{array}{l}0.0238 * \\
(0.0112)\end{array}$ & $\begin{array}{c}0.0216^{*} \\
(0.008)\end{array}$ & $\begin{array}{l}0.019^{*} \\
(0.009)\end{array}$ & $\begin{array}{c}0.028 * * \\
(0.009)\end{array}$ & $\begin{array}{c}0.036^{* *} \\
(0.011)\end{array}$ \\
\hline \multicolumn{9}{|c|}{ Spatial autocorrelation control } \\
\hline $\begin{array}{l}\text { Spatial spillover } \\
\text { effects }\end{array}$ & $\begin{array}{c}0.467 * * \\
(0.114)\end{array}$ & $\begin{array}{c}0.464 * * \\
(0.115)\end{array}$ & $\begin{array}{c}0.279 * * \\
(0.081)\end{array}$ & $\begin{array}{c}0.279 * * \\
(0.081)\end{array}$ & $\begin{array}{c}0.505 * * \\
(0.113)\end{array}$ & $\begin{array}{c}0.506^{* *} \\
(0.114)\end{array}$ & $\begin{array}{c}0.266 * * \\
(0.077)\end{array}$ & $\begin{array}{l}0.251 * * \\
(0.077)\end{array}$ \\
\hline F-value & $213.78 * *$ & $159.79 * *$ & $166.47 * *$ & $127.65^{* *}$ & $196.02 * *$ & $147.07 * *$ & $175.65 * *$ & $130.15^{* *}$ \\
\hline Hansen $\mathbf{J}$ statistic & & & 0.513 & 0.406 & & & $5.692 *$ & $5.661 *$ \\
\hline Observations & 488 & 488 & 427 & 427 & 488 & 488 & 427 & 427 \\
\hline
\end{tabular}

Note: ** significant at 1\%-level; * significant at 5\%-level; standard errors are in parentheses 


\section{References}

Acs, Z.J., Audretsch, D.B., Braunerhjelm, P., Carlsson, B., 2009. The Knowledge Spillover Theory of Entrepreneurship. Small Business Economics, 32(1): 15-30.

Agarwal, R., Echambadi, R., Franco, A., Sarkar, M. B., 2004. Knowledge Transfer Through Inheritance: Spinout Generation, Development and Survival. Academy of Management Journal, 47(4): 501522.

Allen, D., McClusky, R., 1990. Structure, Policy, and Performance in the Business Incubator Industry. Entrepreneurship Theory and Practice, 15(2): 61-77.

Armington C.. Acs, Z. J., 2002. The Determinants of Regional Variation in New Firm Formation. Regional Studies, 36(1): 33-45.

Audretsch, D. B., Fritsch, M., 1994. The Geography of Firm Births in Germany. Regional Studies, 28(4): 359-365.

Audretsch, D. B., Lehmann E. E., 2005. Does the Knowledge Spillover Theory of Entrepreneurship Hold for Regions?. Research Policy, 34(8): 1191-1202.

Audretsch, D. B., Keilbach M., Lehmann, E. E., 2005. The Knowledge Spillover Theory of Entrepreneurship and Technological Diffusion. In: Libecap, G.D. (Eds). University entrepreneurship and technology transfer: Process, Design, and Intellectual Property. (Advances in the Study of Entrepreneurship, Innovation, and Economic Growth - Volume 16). JAI Press.

Audretsch, D. B., 1995. Innovation and Industry Evolution. MIT Press, Cambridge, MA.

Audretsch, D. B., Feldman, M .P., 1996. R\&D Spillovers and the Geography of Innovation and Production. American Economic Review, 86(3): 630-640.

Balestra, P., 1995. Fixed Effect Models and Fixed Coefficient Models, in Matyas L. and P. Sevestre (eds.), The Econometrics of Panel Data. Kluwer Academic Publishers, Dordrecht.

Beesley, M. E., Hamilton M. T., 1984. Small Firms' Seedbed Role and the Concept of Turbulence. Journal of Industrial Economics, 33(2): 217-231.

Brixy, U., Grotz, R., 2007. Regional Patterns and Determinants of the Survival of New Firms in Western Germany. Entrepreneurship and Regional Development, 19(4): 293-312.

Carree, M., Santarelli, E., Verheul, I., 2008. Firm Entry and Exit in Italian Provinces and the Relationship with Unemployment. International Entrepreneurship and Management Journal, 4(2): 171-186.

Caves, R. E., 1998. Industrial Organization and New Findings on the Turnover and Mobility of Firms. Journal of Economic Literature, 36(4): 1947-1982.

Cohendet, P., Llerena, P., Marengo, L., 2000. Is There a Pilot in the Evolutionary Firm? In Foss, N. and Mahnke V. (2000), 95-115.

Davidsson, P., Lindmark, L., Olofsson, C., 1994. New Firm Formation and Regional Development in Sweden, Regional Studies, 28(4): 395-410.

Dosi, G., Marengo, L., 2000. On the Tangled Discourse between Transaction Cost Economics and Competence-Based views of the Firm. In Foss N. and Mahnke V. (Eds) (2000), 80-92.

Dunne, T., Roberts, M., Samuelson, L., 1988. Patterns of Firm Entry and Exit in US Manufacturing Industries. Rand Journal of Economics, 19(4): 495-515.

Evans, D., Leighton, L., 1989. Some Empirical Aspects of Entrepreneurship. American Economic Review, 79(3): 519-535.

Foss, N., Mahnke, V. (Eds), 2000. Competence, Governance, and Entrepreneurship: Advances in Economic Strategy Research. Oxford University Press, Oxford.

Fotopoulos, G., Spence, N., 1999. Spatial Variation in New Manufacturing Plant Openings: Some Empirical Evidence from Greece, Regional Studies, 33(3): 219-229.

Fransman, M., 1999. Vision of Innovation: The Firm and Japan. Oxford University Press, Oxford.

Fritsch, M., 1992. Regional Differences in New Firm Foundation: Evidence from West Germany. Regional Studies, 26(3): 233-241.

Fritsch, M., 2008. How Does New Business Formation Affect Regional Development? Introduction to the Special Issue. Small Business Economics, 30(1): 1-14.

Fritsch, M., Falck, O., 2007. New Business Formation by Industry over Space and Time: A MultiDimensional Analysis. Regional Studies, 41(2): 157-172.

Garofoli, G., 1994. New Firm Formation and Regional Development: The Italian Case. Regional Studies, 28(4): 381-393.

Gaygisiz, E., Koksal, M. Y., 2003. Regional Variation in New Firm Formation in Turkey: CrossSectional and Panel Data Evidence, ERC Working Papers in Economics, 03/08.

General Statistics Office of Vietnam (GSO), 2006. Statistic Yearbook 2005. Statistical Publisher, Hanoi. $347-358$

Guesnier, B., 1994. Regional Variations in New Firm Formation in France. Regional Studies, 28(4): 
Gujarati, D. N., 1988. Basic Econometrics. McGraw-Hill Book Company, New York.

Hart, M., Gudgin, G., 1994. Spatial Variations in New Firm Formation in the Republic of Ireland, 1980-1990. Regional Studies, 28(4): 367-380.

Hausmann, R., Rodrik, D., 2003. Economic Development as Self-discovery, Journal of Development Economics, 72(2): 603-633.

Keeble, D., Walker, S., 1994. New Firms, Small Firms, and Dead Firms: Spatial Patterns and

Determinants in the United Kingdom. Regional Studies, 28(4): 411-427.

Kirzner, I., 1973. Competition and Entrepreneurship. University of Chicago Press, Chicago.

Kirzner, I., 1997. Entrepreneurial Discovery and the Competitive Market Process: An Austrian Approach. Journal of Economic Literature, 35(1): 60-85.

Klepper, S., Sleeper, S. D., 2005. Entry by Spinoffs. Management Science, 51(8): 1291-1306.

Krugman, P., 1991, Geography and Trade. MIT Press, Cambridge, MA.

Lévesque, M., Shepherd, D. A., 2004. Entrepreneurs' Choice of Entry Strategy in Emerging and Developed Markets. Journal of Business Venturing, 19(1): 29-54.

Levine, R., Renelt, D., 1992. A Sensitivity Analysis of Cross-Country Growth Regressions. American Economic Review, 82(4): 942-963.

Mueller, P., 2007. Exploiting Entrepreneurial Opportunities: The Impact of Entrepreneurship on Growth. Small Business Economics 28 (4): 355-362.

Nelson, R. R., Winter, S. G., 1982. An Evolutionary Theory of Economic Change. Harvard University Press, Cambridge, MA.

Penrose, E. T., 1959. The Theory of the Growth of the Firm. New York: Wiley.

Piergiovanni, R., Santarelli, E., 1995. The Determinants of Firm Start-up and Entry in Italian Producer Services. Small Business Economics, 7(3): 221-230.

Rand, J., Tarp, F., 2007. Characteristics of the Vietnamese Business Environment: Evidence from a SME Survey in 2005. Research Report of the Danida Funded Business Sector Program Support.

Reynolds, P., Storey, D. J., Westhead, P., 1994. Cross-national Comparisons of the Variation in New Firm Formation Rates. Regional Studies, 28(4): 443-456.

Reynolds, P., 1994. Autonomous Firm Dynamics and Economic Growth in the United States, 19861990. Regional Studies, 28(4): 429-442.

Santarelli, E., Vivarelli, M., 2007. Entrepreneurship and the Process of Firms Entry, Survival and Growth. Industrial and Corporate Change, 16 (3): 455-488.

Santarelli, E., Carree, M., Verheul, I., 2009. Unemployment and Firm Entry and Exit: An Update on a Controversial Relationship. Regional Studies, 43(8): 1061-1073.

Schumpeter, J. A., 1934. The Theory of Economic Development: An Inquiry into Profits, Capital Credit, Interest and the Business Cycle. Harvard University Press, Cambridge, MA.

Shane, S., 2000. Prior Knowledge and the Discovery of Entrepreneurial Opportunities. Organization Science, 11(4): 448-469.

Shane, S., 2003. A General Theory of Entrepreneurship: The Individual-opportunity Nexus. Edward Elgar Publishing, Cheltenham.

Shane, S., Venkataraman, S., 2000. The Promise of Entrepreneurship as a Field of Research. Academy of Management Review, 25(1): 217-226.

Shepherd, D. A., DeTienne, D. R., 2005. Prior Knowledge, Potential Financial Reward, and Opportunity Identification. Entrepreneurship Theory and Practice, 29(1): 91-112.

Storey, D. J., 1982. Entrepreneurship and the New Firm. Croom Helm, London.

Storey, D. J., 1994. Understanding the Small Business Sector, International Thomson Business Press, London.

Sutaria, V., Hicks, D., 2004. New Firm Formation: Dynamics and Determinants. Annals of Regional Science, 38(2): 241-262.

Teece, D. J., Pisano G., Shuen A., 1997. Dynamic Capabilities and Strategic Management. Strategic Management Journal, 18(7):509-533.

Verheul, I., Carree, M., Santarelli, E., 2009. Regional Opportunities and Policy Initiatives for New Venture Creation. International Small Business Journal, 27(5): 608-625.

Wagner, J., 2004. Are Young and Small Firms Hothouses for Nascent Entrepreneurs?. Applied Economics Quarterly, 50(4), 379-391.

Wagner, J., Sternberg, R., 2004. Start-up Activities, Individual Characteristics, and the Regional

Milieu: Lessons for Entrepreneurship Support policies from German Micro Data. Annals of Regional Science, 38(2): 219-240.

Wang, S., 2006. Determinants of New Firm Formation in Taiwan. Small Business Economics, 27 (45): 313-323.

Wooldridge, J. M., 2002. Econometric Analysis of Cross-Section and Panel Data. MIT Press, 
Cambridge, MA. 


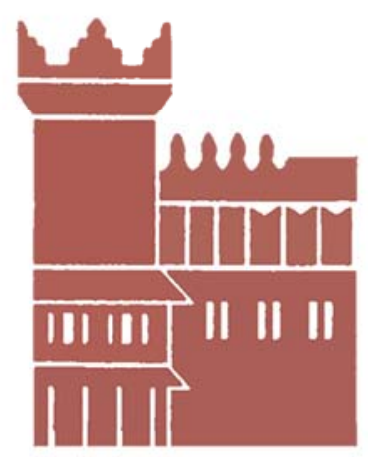

Alma Mater Studiorum - Università di Bologna DEPARTMENT OF ECONOMICS

Strada Maggiore 45

40125 Bologna - Italy

Tel. +39051 2092604

Fax +390512092664

http://www.dse.unibo.it 